Aus der Klinik für Klinische Neurophysiologie

(Prof. Dr. med. W. Paulus)

der Medizinischen Fakultät der Universität Göttingen

\title{
The effect of apomorphine on anodal tDCS-induced cortical plasticity in the human motor cortex
}

\author{
INAUGURAL - DISSERTATION \\ zur Erlangung des Doktorgrades \\ der Medizinischen Fakultät der \\ Georg-August-Universität zu Göttingen
}

vorgelegt von

Lynn Elena Müller

aus Essen

Göttingen 2018 
Dekan:

Referent:

Ko-Referent:

Drittreferent:
Prof. Dr. rer. nat H. K. Kroemer

Prof. Dr. med. M. A. Nitsche

Prof. Dr. Swen Hülsmann

Prof. Dr. Dirk Wedekind

Datum der mündlichen Prüfung: Dienstag den 13.11.2018 
Hiermit erkläre ich, die Dissertation mit dem Titel "The effect of apomorphine on anodal tDCS-induced cortical plasticity in the human motor cortex" eigenständig angefertigt und keine anderen als die von mir angefertigten Hilfsmittel verwendet zu haben.

Berlin, den 02.03.2018 


\section{Table of Contents}

Abbreviations

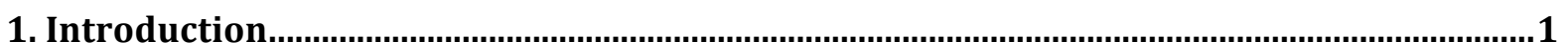

1.1 Plasticity in the Central Nervous System ……......................................................................................

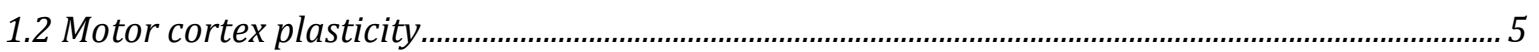

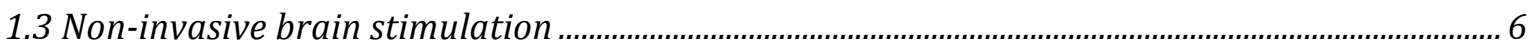

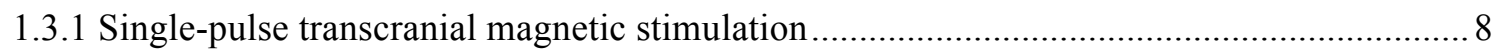

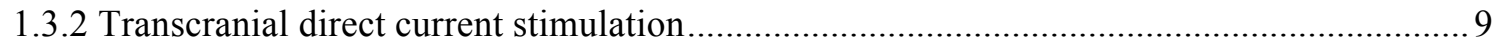

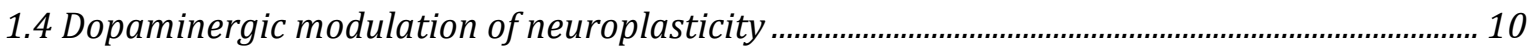

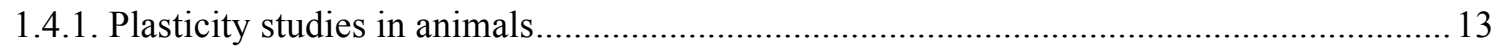

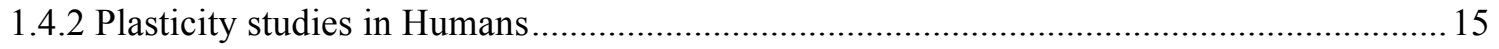

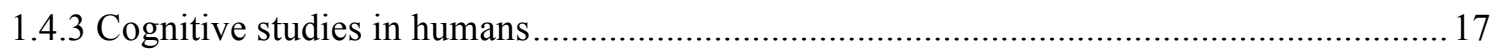

1.5 Apomorphine

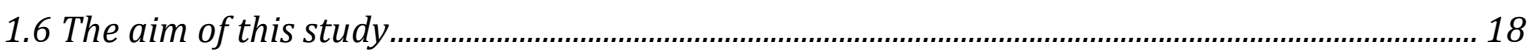

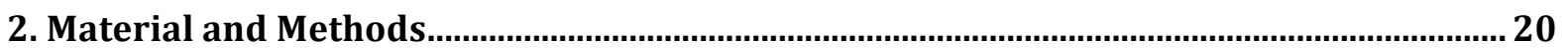

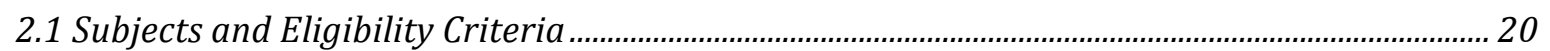

2.2 Monitoring corticospinal excitability with TMS ............................................................................ 21

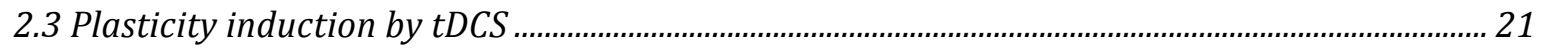

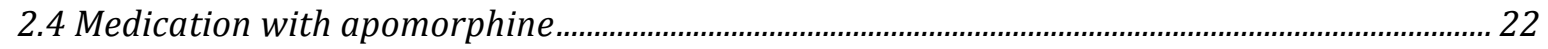

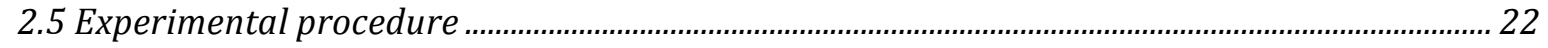

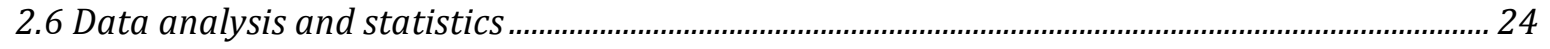

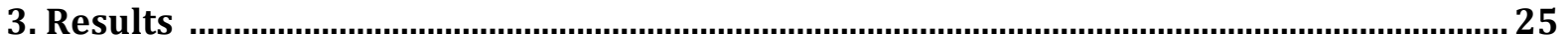

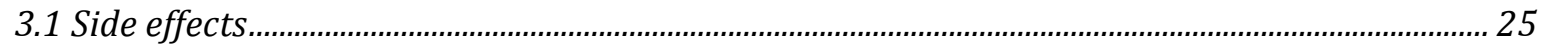

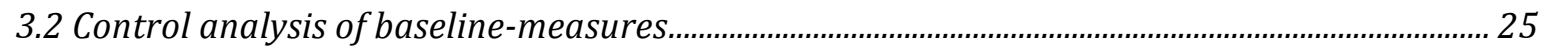

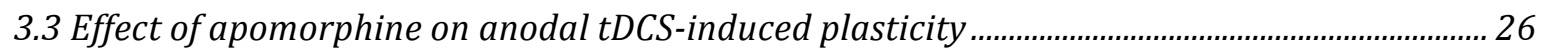

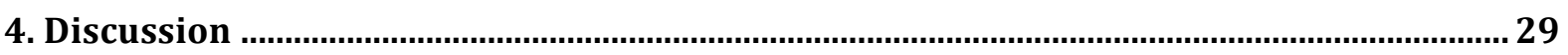

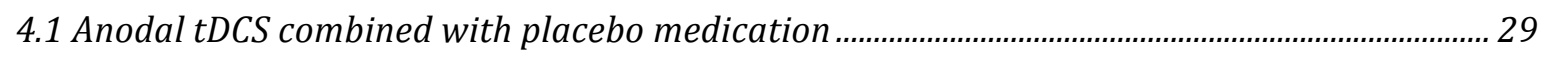

4.2. Anodal tDCS with apomorphine condition ...................................................................................... 29

5. Summary

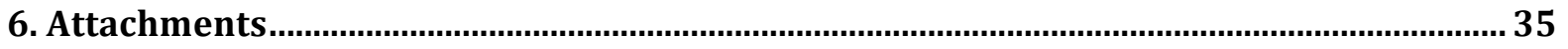

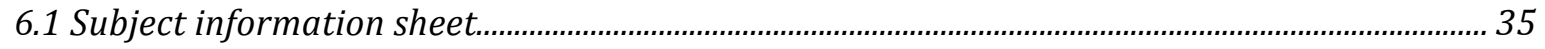

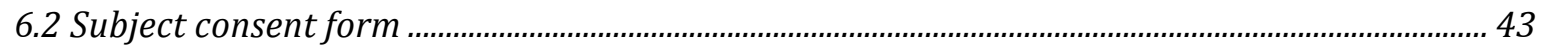

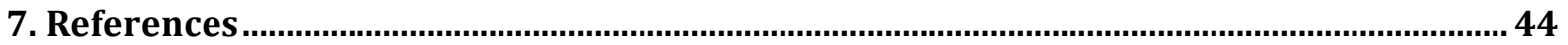




\section{Abbreviations}

AC adenylyl cyclase

ADM abductor digiti minimi muscle

AMPA $\alpha$-amino-3-hydrox-5-methyl-4-isoxazolepropionic acid

ANOVA analysis of variance

AP action potential

BL baseline

CaMKII $\mathrm{Ca}^{2+} /$ calmodulin-dependent protein kinase II

cAMP cyclic adenosine monophosphate

CNS central nervous system

CREB cAMP-responsive element-binding proteins

DA-R dopamine receptor

D1 dopamine receptor group 1: consisting of dopamine receptors 1 and 5

D2 dopamine receptor group 2: consisting of dopamine receptors 2, 3 and 4

DF degrees of freedom

EMG electromyographic

F $\quad$ F-statistic

GABA gamma-aminobutyric acid ( $\gamma$-aminobutyric acid)

Gi a subtype of G-protein-coupled receptors

Gs a subtype of G-protein-coupled receptors

iPAS inhibitory paired associative stimulation

L-dopa l-3,4-dihydroxyphenylalanine

LTD long-term depression

LTP long-term potentiation

M1 primary motor cortex

MEP motor evoked potential

NA next afternoon

NE next evening

NIBS non-invasive brain stimulation techniques

NM next morning

NMDA n-methyl-D-aspartate receptor 
PAS paired associative stimulation

PP1 protein phosphate 1

PKA protein kinase A

rTMS repetitive transcranial magnetic stimulation

SE same evening

SEM standard error of the mean

Sig significance

SSRI selective serotonin re-uptake inhibitors

SULP sulpiride

TBS theta-burst stimulation

tDCS transcranial direct current stimulation

TES transcranial electric stimulation

TMS transcranial magnetic stimulation 


\section{Introduction}

Neuroplasticity is the remarkable anatomical and functional change of our brain that allows us to adapt and therefore to learn and remember new things. It is essential for humans from infancy when we start reacting to our outside environment until later in life when we have to maximize our remaining capacity in order to adjust to the continually changing environment. Furthermore, it is crucial for recovery after central nervous system (CNS) injury or diseases such as stroke (Pascual-Leone et al. 2005) or multiple sclerosis (Ksiazek-Winiarek et al. 2015). Maladaptive neuroplasticity on the other hand is thought to be an underlying process in neurodegenerative and neuropsychiatric diseases (Kolb and Gibb 2014).

So how does neuroplasticity work? As early as 1949 , Hebb stated that the basis of neuroplasticity lies within the synapses (Hebb 1949). He studied how synaptic connections are strengthened when they are activated at the same time. Nowadays, our understanding has greatly advanced and concepts such as long-term potentiation (LTP) and long-term depression (LTD) have been studied extensively. Proteins, genes and other target molecules which are supposed to play key roles in neuroplasticity have been found (Malenka and Bear 2004). Furthermore, the role of neuromodulators such as dopamine, which primarily do not induce plasticity themselves but can facilitate or inhibit it, has received increasing attention (Nitsche et al. 2012). They are thought to exert a crucial role in the modulation of neuroplasticity and hence might control learning and memory formation.

Much of the research on neuroplasticity has been done in animal models. However, new non-invasive brain stimulation techniques (NIBS) such as transcranial magnetic stimulation (TMS) and transcranial direct current stimulation (tDCS) have 
been developed, allowing us to study neuroplasticity in the human brain and hopefully setting the groundwork for further research in understanding neuroplasticity more thoroughly. With a more in depth understanding of neuroplasticity, one can hope to find therapeutic strategies to stimulate plasticity in the damaged CNS. This would greatly advance treatment options for neurodegenerative diseases such as Alzheimer's disease, which remain untreatable until now. This holds true also for other diseases that go along with a structural change or altered plasticity in the brain, such as stroke, MS, or even depression (Knable et al. 2002; Floel and Cohen 2010; Boggio et al. 2011; Dimyan and Cohen 2011).

In this thesis I will first elaborate the concept of neuroplasticity in general and then in the motor cortex. I will then introduce non-invasive brain stimulation techniques such as TMS and tDCS, which allow us to induce and monitor plasticity in the human brain. Furthermore, I will give an overview of the role of dopamine in neuroplasticity. Based on this background I define the aims and hypothesis of my research: the investigation of the effect of apomorphine, a global dopamine agonist, on motor cortex plasticity in humans, which I will then present.

\subsection{Plasticity in the Central Nervous System}

Neuroplasticity, the ability of the brain to reorganize itself structurally and functionally in response to environmental changes, is thought to be the underlying mechanism of learning and memory. Plastic changes of brain structure and function occur on a variety of levels.

At the microscopic level, as Donald Hebb postulated, during the process of learning, whenever pre- and postsynapses are activated simultaneously, a lasting 
metabolic change and growth process occurs which leads to the strengthening of the synapses involved (Hebb 1949). Over the last 50 years our knowledge of those metabolic changes and growth processes has greatly advanced. The long lasting forms of synaptic plasticity, which may last up to days or even years, pose a viable model for learning (Rioult-Pedotti et al. 2000) and long-term memory storage (Citri and Malenka 2008). LTP and LTD have been thoroughly studied, especially in glutamatergic synapses in the CA1 region of the hippocampus in animals. Binding to its n-methyl-D-aspartate (NMDA) receptors and thus activating calcium channels, glutamate, the main excitatory neurotransmitter in the human brain, causes an increase in post-synaptic calcium concentration and depending on the level of calcium influx either LTP (high calcium influx) or LTD (low calcium influx) can be induced (Lisman 2001). High calcium concentration activate, among others, the calcium dependent kinase (CaMKII), which leads to an insertion of $\alpha$-amino-3-hydrox-5-methyl-4-isoxazolepropionic acid (AMPA) receptors in the postmembrane (Malinow and Malenka 2002). A low calcium influx, on the other hand, which occurs when the presynapses fire asynchronously or with low frequency, leads to an activation of the protein phosphatase 1 (PP1), which in turn dephosphoralizes and thus inactivates the CaMKII, causing a decrease in postsynaptic AMPA receptors (D' Alcantara et al. 2003). Between the thresholds of high or low postsynaptic calcium concentration that either triggers LTP or LTD respectively exists a so called "no-man's land", which does not result in any plasticity changes (Lisman 2001). Moreover, a very high calcium influx leads to an excitability reduction, as this high increase in calcium results in a dephosphorylation and activation of potassium channels, which then causes a reduction of neuronal activity through hyperpolarization (Misonou et al. 2004). 


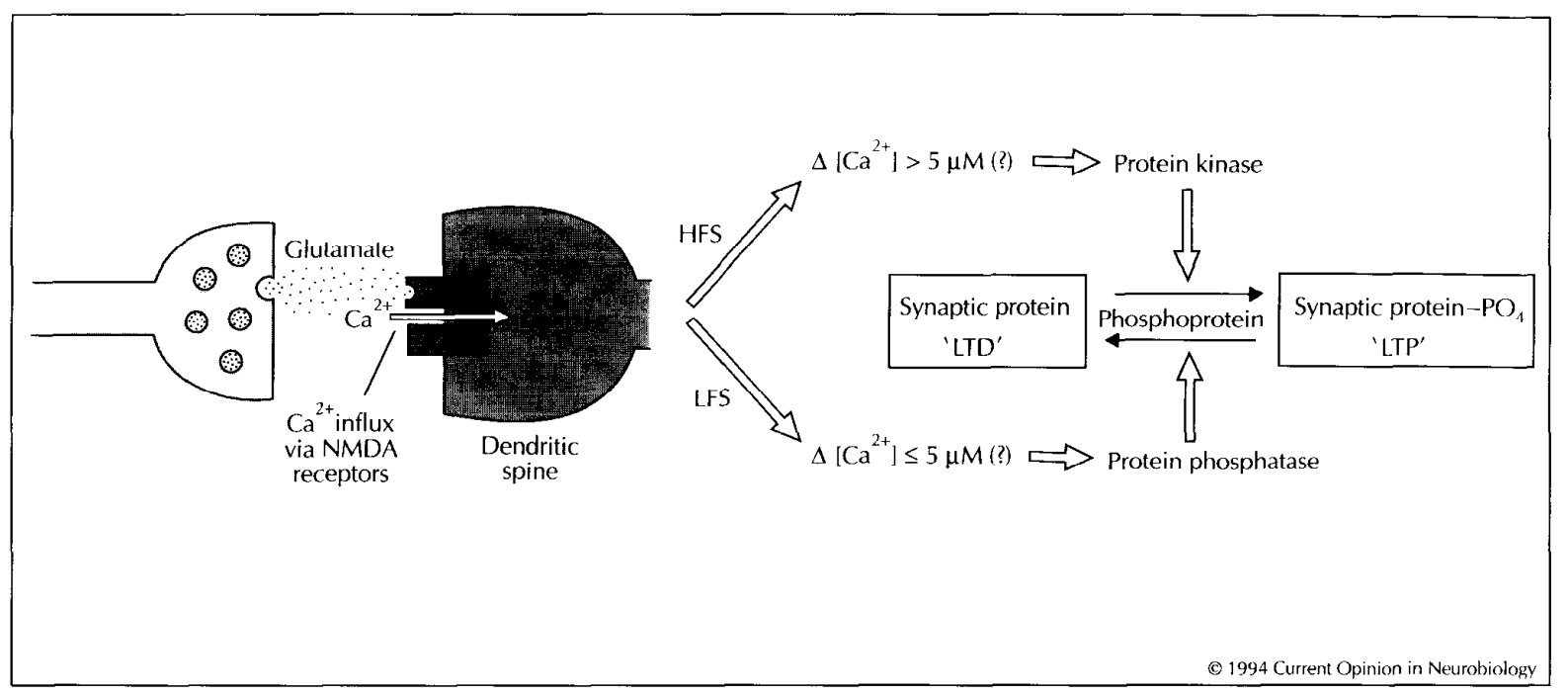

Fig.1 Simplified model illustrating the induction of LTP and LTD.

Glutamate release of the pre-synapse leads to an increase of calcium influx in the postsynapse. Depending on the amount of calcium, either LTP is induced (high level of Ca2+ influx) or LTD is induced (low level of Calcium influx). (With frienldy permission taken from Bear and Malenka 1994)

Despite the knowledge obtained so far, we are still faced with many questions and our search for a clear physiologic mechanism behind plasticity goes on (Bliss et al. 2003). Figure 1 shows a simplified model of how LTP and LTD work in their prototypic form of a glutamatergic synapse in the hippocampus: not only the intracellular calcium concentration is important (Lisman 2001), but also pre- and post synapse involvement (Malenka and Bear 2004), as well as the time point of activation (Citri and Malenka 2008) play a crucial role. The model of spike timing dependent plasticity illustrates that whether a synapse is strengthened or weakened changes if presynaptic spike arrival is milliseconds before or after postsynaptic spikes (Sjöström and Gerstner 2010). In some synapses, LTP does not depend on NMDA receptors but instead on kainate receptors (Bliss et al. 2003) and gamma-aminobutyric acid (GABA) interneurons which are also important for the modulation of plasticity induction (Trepel and Racine 2000). Much more to the point however, a heterogeneous group of neurochemicals, known as neuromodulators, also play a crucial role in modulating plasticity, especially in the neocortex. One of the most intensely studied neuromodulator is dopamine as it is 
thought to play an important role in learning and memory formation. Before elaborating on the role of dopamine in neuroplasticity in chapter 1.4 , motor cortex plasticity will be explained in chapter 1.2 and the non-invasive brain stimulation tools TMS and tDCS, which allow the investigation of plasticity in humans, will be explained in chapter 1.3.

\subsection{Motor cortex plasticity}

Most of the experimental animal and in vitro LTP / LTD studies have been conducted in the hippocampal area of the brain or with cells of this area, because the hippocampus plays an important role in memory formation and thus glutamatergic hippocampal LTP has become the prototype for synaptic plasticity (Citri and Malenka 2008). However, this area would not be easily suitable for neuroplasticity research in humans as it is not easily accessible for direct study of neurophysiological mechanisms in humans via electroencephalographic or non-invasive brain stimulation approaches because of its distance from the scalp surface. Alternatively, the primary motor cortex (M1) has been shown to be a suitable region for examining plasticity as it is situated at the cerebral surface and thus accessible for non-invasive brain stimulation. Additionally, one can obtain objective output parameters for probing induced excitability changes indicative of plasticity. Thirdly, the human motor cortex is well explored and plasticity of this region has been thoroughly studied (Sanes and Donoghue 2000; Pascual-Leone et al. 2005). Much more to the point, the plasticity induced in the motor cortex shares similarities with hippocampal plasticity as motor learning and cognition are also based on the principle of activity-driven synaptic strength changes (Sanes and Donoghue 2000). Not only in animal studies but also in human studies, motor cortex plasticity has been revealed and its importance for recovery after damage such as stroke has drawn 
increasing attention to this field (Hallett 2001). The somatotopic representation of the body within the primary motor cortex underlies constant reorganization due to injuries such as nerve lesion or limb amputation but also due to simple training, such as repetition of basic movements (Classen et al. 1998; Stefan et al. 2000). It is thought that horizontal inter-neurons within M1, which form neuronal assemblies that could be the construct of such dynamic motor representations, are the substrate for M1 plasticity (for a review see (Sanes and Donoghue 2000)).

\subsection{Non-invasive brain stimulation}

With the development of NIBS, a new field of research has emerged which includes plasticity studies within the human brain.. Depending on the technique and protocol, NIBS enable us to probe the excitability of the human brain through single pulse transcranial magnetic stimulation (TMS) or they can induce plasticity (such as tDCS, PAS, repetitive TMS).

The first method that was invented was transcranial electric stimulation (TES), which uses high voltage current to induce action potentials (AP) of cortical neurons under the electrodes. This procedure is however painful because not only the cortical neurons are activated, but also nerve endings in the skin and head muscles and thus it is not well-suited for research purposes. Thereafter TMS was introduced (Barker et al. 1985). Working with a strong magnetic pulse, which, after penetrating the skull induces an electric field in the brain, TMS applied above the motor cortex in moderate intensities does not cause pain (Barker et al. 1985; Rothwell 1993), because the induced current does not active the pain fibre nerve endings in the skin or the head muscles. Furthermore, TMS has the advantage over TES that magnetic stimulation is diffuse at the surface and thus does not cause high current densities directly underneath the 
stimulation coil (Barker and Freeston 2007). Hence TMS became popular for research and since its discovery an innumerable amount of studies have used single pulse TMSelicited motor evoked potentials (MEP) as a tool to monitor or repetitive TMS (rTMS), patterned rTMS or other protocols to induce plastic changes. RTMS induces frequencyspecific after-effects, with high frequency rTMS ( $\geq 5 \mathrm{~Hz})$ increases and low frequency rTMS $(\leq 1 \mathrm{~Hz})$ decreases excitability (Liew et al. 2014).

Other techniques that induce plasticity within the human cortex are: transcranial direct-current stimulation (tDCS) and paired associative stimulation (PAS), etc. (for a review (Vallence and Ridding 2014)). As we have used tDCS to induce plasticity and single pulse TMS to monitor those changes, both techniques will be explained in more detail in the following chapter. PAS combines a TMS pulse with low-frequency electric suprathreshold peripheral nerve stimulation, which, depending on the interstimulus interval between peripheral and TMS pulse, induces excitatory or inhibitory plasticity. PAS after-effects share some characteristics with those of tDCS, as they are also NMDA receptor and calcium dependent (Stefan et al., 2002) and therefore thought to be LTPand LTD-like. Unlike tDCS, which affects a big population of neurons under relatively large stimulation electrodes, PAS is thought to be focal and synapse-specific, affecting only small, specific population of neurons (Stefan et al. 2002; Classen et al. 2004). 


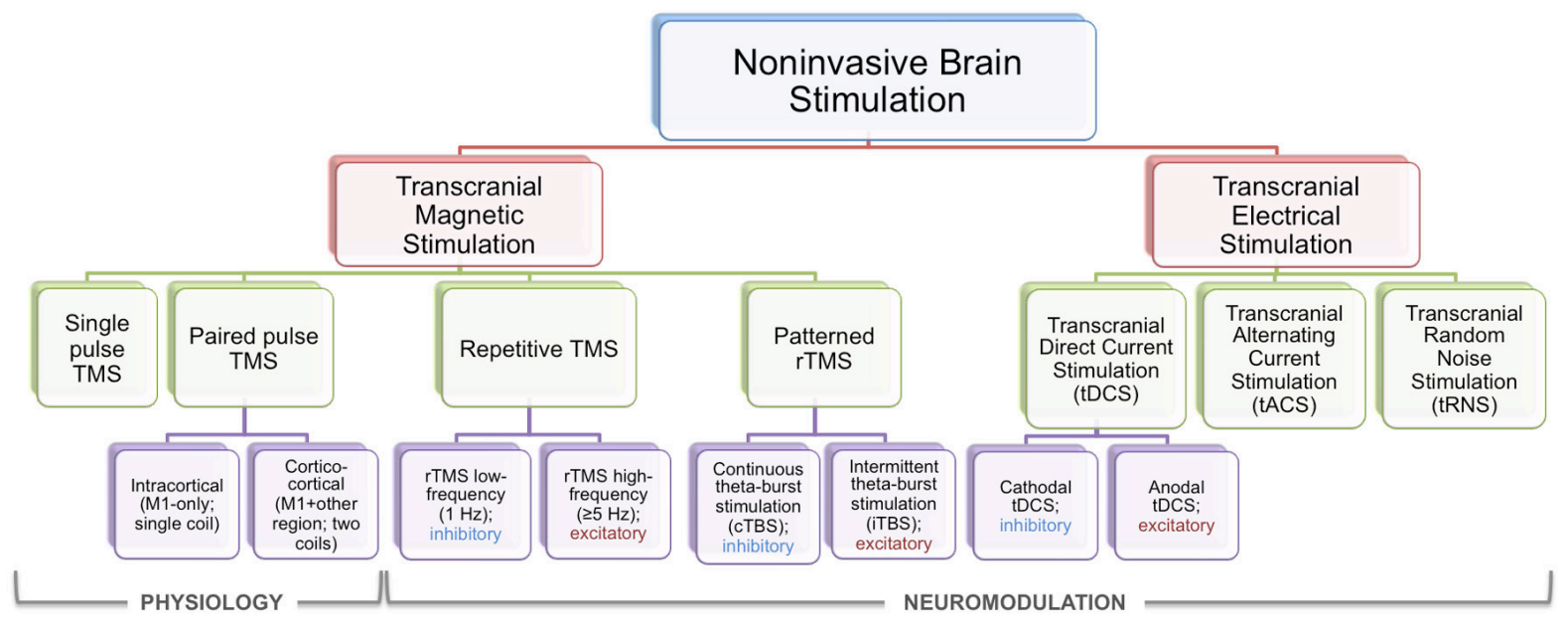

Fig. 2 NIBS schematic chart

Chart illustrating different TMS and tES techniques that either measure (physiology) or induce (neuromodulation) neuroplasticity. (With friendly permission figure taken from Liew et al. 2014).

\subsubsection{Single-pulse transcranial magnetic stimulation}

Single-pulse TMS is an approved technique to monitor corticospinal excitability and quantify motor-cortical neuronal responses. It is based on the principle of electromagnetic induction (Nahas 2003). Generating a magnetic field above the skull, the TMS coil induces a secondary electrical current flow in the cortical area underneath. If the current is sufficiently large, the cortical neurons are depolarized. In the motor cortex this leads to excitation of corticospinal projections because the cortical neuron activates the respective pyramidal tract neurons, which in turn causes a muscle response (Di Lazzaro et al. 1998). This can be recorded as motor evoked potential (MEP) of the muscle representing the stimulated cortical area. The amplitude of the MEP represents corticospinal excitability. An increased excitability will result in enhanced MEP amplitudes and a decrease of excitability in reduced MEP amplitudes respectively. The muscle activities can be recorded using surface electromyography electrodes and the size of the MEP amplitudes can be used to index the changes in excitability before and after intervention with NIBS or pharmacological agents (Rothwell 1993). 


\subsubsection{Transcranial direct current stimulation}

Nitsche and Paulus (2000) have shown that transcranial direct current stimulation (tDCS) is an eligible non-invasive method to modulate cortical excitability also in humans. Animal experiments show that delivering weak subthreshold direct current through two surface electrodes on the scalp does not induce an action potential, but alters the membrane resting potential of the affected neurons, and consequently alters the neuronal excitability and spontaneous neuronal activity (Nitsche et al. 2008).

So-called "anodal tDCS" over the motor cortex is attained by positioning the anode over the target area and the cathode over the contralateral orbit. The respective current flow results in depolarizing effects on membranes of cortical neurons and thus leads to an increase in cortical excitability. Cathodal tDCS on the other hand works vice versa and hyperpolarizes the resting membrane potential, hence decreasing cortical excitability. Depending on the stimulation duration, after-effects can be induced which last up to 60 minutes in humans when tDCS is applied for 9-13 minutes (Nitsche and Paulus 2000; Nitsche and Paulus 2001; Nitsche et al. 2003a). Furthermore, it was shown that those after-effects are abolished by NMDA receptor antagonists (Fritsch et al. 2010, Liebetanz et al. 2002) and that they are calcium channel dependent (Nitsche et al. 2003b), thus suggesting that tDCS-induced neuroplasticity shares common mechanisms with LTP and LTD (Vallence and Ridding 2014). However, all underlying cortical neurons and also adjacent cortical areas are stimulated nonspecifically, so the effect is not focal (Figure 2). The larger the electrode, the less focal the stimulation (Nitsche et al. 2008), or vice versa, the smaller the stimulation electrode and bigger the reference electrode, the more focused is the tDCS-generated modulation of cortical excitability (Nitsche et al. 2007). Furthermore, there is an inter-individual variation of tDCS- 
induced current flow across subjects (Datta et al. 2012; Wiethoff et al. 2014; Strube et al. 2016).
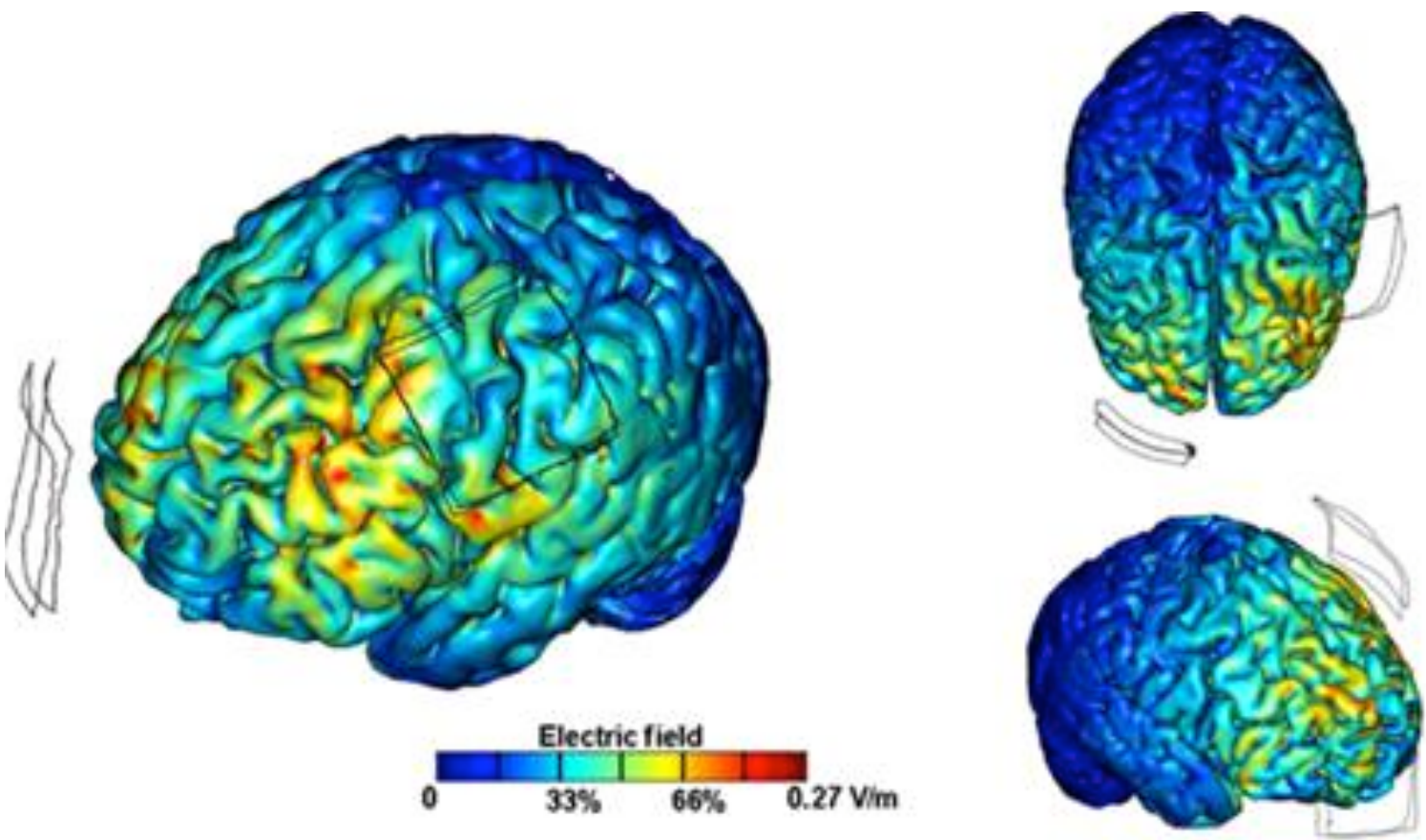

Fig 3. Graphical illustration of the induced cortical surface electric field (EF) after tDCS

The graph illustrates that tDCS-induced after effects are non-focal, as the adjacent cortical areas are also stimulated. Figure adapted from (with friendly permission taken from Datta et al. 2012).

\subsection{Dopaminergic modulation of neuroplasticity}

In neurological and psychiatric disorders, most of our pharmacological treatment options influence the level of neurotransmitters and neuromodulators in the brain. For instance selective serotonin re-uptake inhibitors (SSRI), a widely used antidepressantgroup, increase the level of serotonin by blocking its uptake. However, even though it could be shown that psychiatric medications are effective, the underlying physiological mechanisms remain often unclear. It is known, though, that different neurotransmitter systems play different roles in the plasticity of the cortex. Whereas some of the 
neurotransmitters such as glutamate and GABA can directly induce plasticity, other neurotransmitters only have a modulatory impact, hence they are also called neuromodulators. This means that they can induce little or no change in basal neuronal activity, but they can either potentiate or attenuate responses elicited by other neurotransmitters (Barchas et al. 1978). They do this either by changing the excitability of cortical neurons, by alteration of the signal to noise ratio of neuronal responses, or by modulating the threshold of activity-dependent changes at the synapses ( $\mathrm{Gu} 2002)$. How they influence long-term synaptic changes is dependent on various factors, such as receptor subtypes, the concentration and phasic activity of the modulators and the site of action (Nitsche et al. 2012).

Dopamine is one of the most thoroughly studied neuromodulators, as the deregulation of the dopaminergic system is linked to many diseases, including Parkinson's disease, Tourette's syndrome, schizophrenia, attention deficit hyperactive disorder (ADHD) and pituitary tumors (Vallone et al. 2000). Furthermore, dopamine agonists and antagonists are widely used as pharmacological treatment options for Parkinson's disease and as antipsychotic medication respectively. Dopamine also plays a crucial role in the modulation of memory formation and synaptic plasticity (Moal and Simon 1991; Jay 2003). Binding to specific presynaptic or postsynaptic membrane receptors in many different areas of the brain, dopamine exerts its various actions. There are five different dopamine receptors (DA-Rs), D1 to D5, all of which belong to the group of G-protein-coupled receptors. They can be roughly divided into D1 and D2 groups. The D1 group consists of D1 and D5 receptors. The receptors are Gs receptors and thus activate the adenylyl cyclase (AC), which stimulates cAMP formation (Vallone et al. 2000; Gu 2002), causing activation of protein kinase A (PKA). PKA exerts many different functions, among others the stimulation of transcription factors, such as cAMP- 
responsive element-binding proteins (CREB), modification of synapses, and control of ion channels (for overview see Seamans \& Yang 2004).

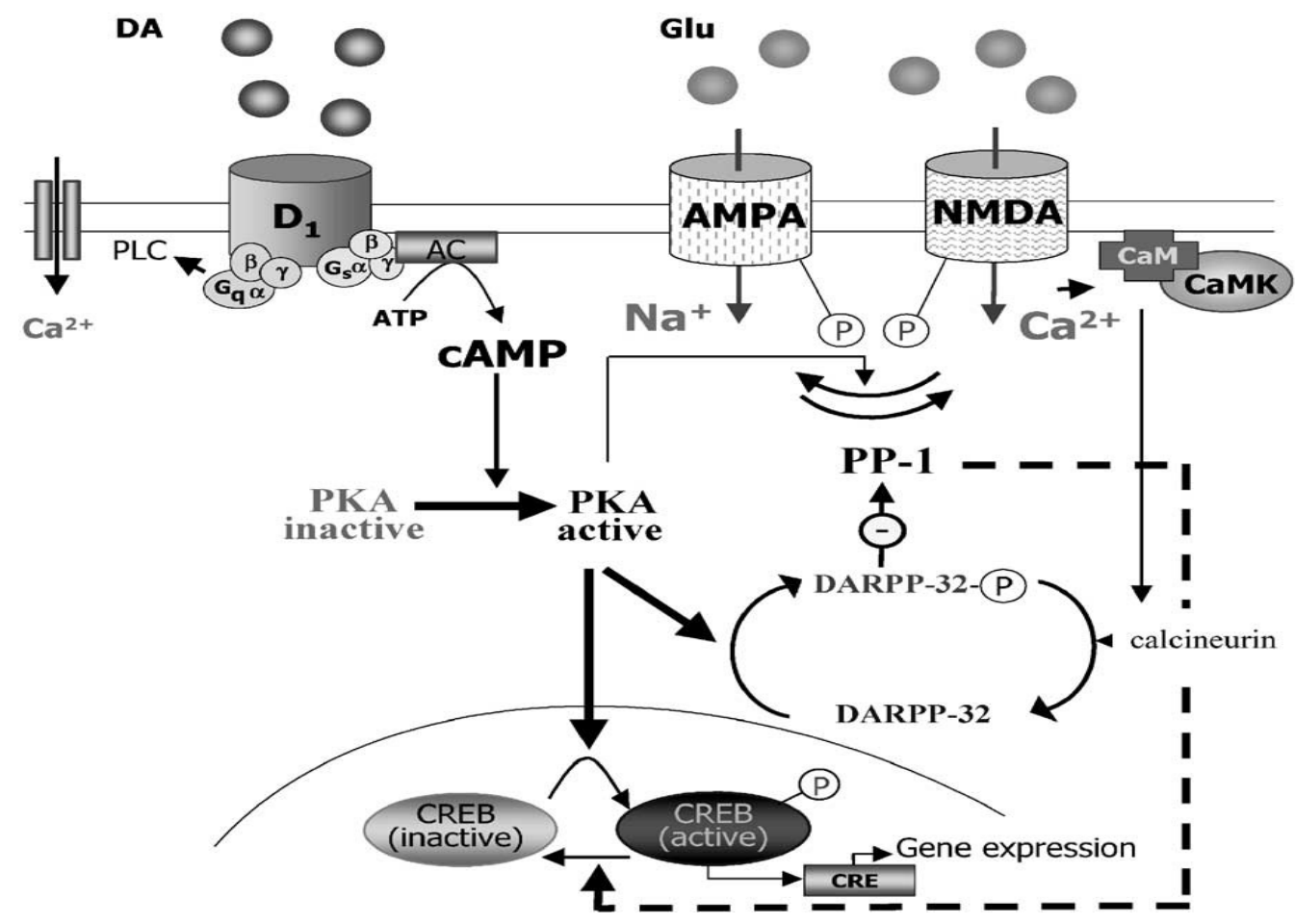

Figure 4: Schematic representation of D1 group receptors signaling pathway

Once dopamine binds on D1 receptor, AC is activated, which leads to the formation of CAMP. Consequently PKA is activated, which in turn stimulates CREB-dependent gene expression. With friendly permission taken from (Jay 2003).

The D2 group consists of D2, D3 and D4 receptors and presynaptic autoreceptors, which are Gi receptors and hence inhibit the activation of AC.

Being one of the major neuromodulators in the brain, dopamine has been extensively studied. It would be beyond the scope of this thesis to summarize all dopamine-related studies. In the present work we will focus on studies that examine the dopaminergic modulation of neuroplasticity. Those studies can be divided into two groups: plasticity studies in animals, which will be discussed in chapter 1.4.1, and plasticity studies in humans, which will be presented in chapter 1.4.2 


\subsubsection{Plasticity studies in animals}

The role of dopamine on plasticity is complex, because on the one hand it depends on the receptor subtype that is activated and on the other hand it varies according to which brain region is involved. Both in vitro and in vivo studies examined the role of dopamine on LTP and LTD in the hippocampus, the neocortex and the striatum (Jay 2003). Whether D1 or D2 receptors are activated depends, among other things, on the level of dopamine concentration. Low and moderate concentrations of dopamine rather activate D1 receptors and presynaptic D2 autoreceptors, whereas high concentrations of dopamine also activate postsynaptic D2 receptors (Zheng et al. 1999).

Trying to give a general overview of the dopamine receptor functions, one can say that D1 and D5 receptor activation leads to an increase in plasticity. Lemon and Manahan-Vaughan (2006) showed that by stimulation of the D1 receptor subgroup the threshold for LTP, as well as LTD induction, is lowered (Lemon and Manahan-Vaughan 2006). It is thought that this process is regulated through cAMP-dependent mechanisms (Bailey et al. 2000; Sajikumar and Frey 2004; Tseng and O’Donnell 2004). Other studies also show that D1 receptor activation plays an important role in LTP (Otmakhova and Lisman 1996; Bailey et al. 2000; Gurden et al. 2000; Centonze et al. 2001; Kerr and Wickens 2001; Huang et al. 2004; Hansen and Manahan-Vaughan 2014) and LTD induction (Calabresi et al. 1992; Chen et al. 1996; Calabresi et al. 2000). In contrast, D1 receptor group activation can also completely reverse LTP formation into LTD (Mockett et al. 2007).

Activation of D2-receptor results in mixed effects. On the one hand, it has been reported that D2 activation leads to an inhibition of LTD (Chen et al. 1996) and reduction of NMDA as well as GABAergic interneuron activation (Seamans and Yang 2004; Tseng and O'Donnell 2004). On the other hand, studies have shown an increase in 
LTP (Frey et al. 1989; Manahan-Vaughan and Kulla 2003; Abe et al. 2008) and LTD induction (Otani et al. 1998; Spencer and Murphy 2000; Centonze et al. 2001; Tang et al. 2001).

In order to explain these controversial findings, it was proposed that the function of dopamine on neuroplasticity does not only depend on receptor subtype and brain region. It also depends on the timing of glutamate-dopamine interaction (Mockett et al. 2007) and on duration of dopamine receptor stimulation, as well as on concentration level of dopamine (Seaman and Yang 2004). For instance, some of the conflicting findings of D1 receptor group activation could be explained with the concept of a inverted U-shaped dose response profile of D1 activation, meaning that low and high levels of dopamine inhibit plasticity, whereas moderate levels increase it (Seamans and Yang 2004). Furthermore, the focusing concept suggests that the effect of dopaminergic stimulation also depends on the level of cortical activity: high activity states will be further enhanced through D1 receptors (see also above), whereas D2 receptormediated reduction of cortical activity enhance flexibility of cortical activation patterns. This hypothesis is further supported by computational modeling (Durstewitz et al. 2000). Durstewitz and colleagues (2000) illustrated that if D1 modulation predominates, strong activity states benefit because D1 activation enhances this activity, thus allowing a stabilization of the network representation. Furthermore, they propose that the underlying mechanism of how dopamine D1 receptors stabilize networks is by an increase in NMDA and a reduction in AMPA conductance. Moreover, by increasing GABAa conductance after stimulation of D1 receptors, spontaneous switches to other states, that are task-irrelevant, are prevented (Durstewitz et al. 2000). On a cognitive level, similar findings have been reported. Cognitive stability is increased by rendering against interfering stimuli or noise, thus enhancing the signal to noise 
ratio. D1 activation leads to a prioritizing of information storage (Hansen and ManahanVaughan 2014). For instance, tasks that require an early stabilization of a constant neuronal activation circuit, such as simple reaction time task, are enhanced through D1 stimulation. D2-dominated states on the other hand are beneficial for tasks that require high flexibility in choosing between different low activity states. D2 receptor stimulation, contrary to $\mathrm{D} 1$, leads to a reduction in NMDA receptor activity and LTP formation, which in turn leads to a defocusing effect of the neuronal circuit. Furthermore, GABAergic currents are inhibited, thus allowing to alternate between different neuronal circuits (Cools and D’Esposito 2011).

Summing up, the focusing concept suggests that low but still effective dosages of dopamine activate D1 receptors and thus increase highly active networks, allowing them to pursue a goal by stabilizing the network and thus decreasing the influence of distractors. High or very low concentrations of dopamine rather activate D2 receptors and increase performance in tasks that require a high flexibility by allowing multiple representations of different low activity states.

\subsubsection{Plasticity studies in humans}

The effects of dopamine on plasticity in humans have also been explored. Two studies examined the effect of different levels of 1-3,4-dihydroxyphenylalanine (L-dopa) on human motor cortex plasticity. They demonstrated a non-linear dosage-dependent effect of dopamine for both facilitatory and inhibitory plasticity, as both low (25 mg) and high doses (200 mg) of L-dopa impaired PAS- and tDCS-induced plasticity, while under medium (100 mg) dosage preserved and even prolonged the plasticity induced by PAS and cathodal tDCS. anodal tDCS-induced LTP-like plasticity was reversed into 
inhibition (Monte-Silva et al. 2010; Thirugnanasambandam et al. 2011). Another study testing the effect of $100 \mathrm{mg}$ L-dopa on motor cortex plasticity also reports that the focal PAS-induced plasticity is prolonged by dopamine, whereas non-focal anodal tDCS no longer increased and even reduced motor cortex excitability in the L-dopa condition. These results of global phasic dopamine effect are in line with the focusing hypothesis of dopamine (Kuo et al. 2008).

Different dosages $(2.5,10$ and $20 \mathrm{mg})$ of bromocriptine, a selective D2 receptor agonist, combined with tDCS and PAS prevented plasticity alterations in all conditions for anodal tDCS, and in low and high dosages for cathodal tDCS and both PAS conditions. Medium dosages on the other hand preserved plasticity induced by cathodal tDCS, inhibitory and to a lesser degree facilitory PAS, and thus also revealed a dose-dependent modulation for D2 receptors (Fresnoza et al. 2014a). In contrast, blocking the D2 receptor with sulpiride (SULP) resulted in abolishment of iPAS, as well as anodal and cathodal tDCS elicited after-effects (Nitsche et al. 2006; Nitsche et al. 2009). Similar to that, neuroplasticity elicited by theta-burst stimulation (TBS), a specific rTMS protocol, was also impaired by SULP (Monte-Silva et al. 2011).

To study the influence of D1 receptors on human motor cortex plasticity is more challenging, as there are no selective agonists or antagonists applicable for human use. Hence, the relative D1 receptor contribution can only be tested indirectly, by blocking D2 receptors and increasing the activity of D1 receptor by applying either L-dopa (Nitsche et al. 2009; Fresnoza et al. 2014b) or pergolide (Nitsche et al. 2006). Combining $100 \mathrm{mg}$ of L-dopa with the D2 blocker sulpiride preserved the plasticity induced by PAS and tDCS, showing that D1 receptor activation is relevant for plasticity induction in the human motor cortex (Nitsche et al. 2009). Combining sulpride with three different dosages of L-dopa (25, 100 and $200 \mathrm{mg}$ ) revealed a dose-dependent 
modulation for D1 receptor activation (Fresnoza et al. 2014b). An inverted U-shape effect, meaning that only medium dosages (100 mg L-dopa) lead to a preservation in plasticity was observed for anodal tDCS, cathodal tDCS, and excitatory PAS. Activating the D1 receptor by pergolide, which has a relatively low affinity to D1 receptors, plus sulpiride reduced the after-effects of tDCS (Nitsche et al. 2006).

Summarizing the findings of plasticity studies in humans: one can say that global phasic dopaminergic activation in medium dosage with L-dopa (100 mg) leads to an increase in inhibitory plasticity, reverses non-focal excitatory into inhibitory plasticity and strengthens focal facilitatory plasticity. Similar results have been observed with medium dosages of tonic D2 receptor activation with bromocriptine $(10 \mathrm{mg})$. However, D1 receptor activation increases excitatory plasticity regardless of focality and decreases inhibitory plasticity. The inverted U-shaped effect, meaning that medium dosages enhance or preserve plasticity, whereas high and low doses abolish plasticity, was observed for global dopamine activation, as well as for D1, D2 and D2 and D3 receptor activation (Monte-Silva et al. 2009; Monte-Silva et al. 2010; Thirugnanasambandam et al. 2011; Fresnoza et al. 2014a; Fresnoza et al. 2014b).

\subsubsection{Cognitive studies in humans}

It is also thought that dopamine plays an important role in neuroplasticity in humans and hence in learning and memory formation. In line with that, studies testing learning and memory have shown an enhancing effect of dopamine. For instance, increase of global dopamine level with $100 \mathrm{mg}$ of levodopa in healthy subjects during repetitive training improved word learning (Knecht et al. 2004), increased motor memory formation in healthy young subjects, and restored the capability to form a motor 
memory in elderly subjects (Flöel et al. 2005). A beneficial effect of learning was also reported in acute and chronic stroke patients (Scheidtmann et al. 2001; Floel et al. 2005; Rösser et al. 2008). However, like in animal studies, in human studies there has been found contrasting data in regard to the effect of dopamine receptor subtype stimulation. In line with the focusing theory developed in animal studies, Costa et al. (2014) showed in human cognition studies that there is a focusing effect as well, which can explain the contrasting data. In this study task performances that require cognitive stability, like simple repetitive tasks, are facilitated by tonic D1 activation, whereas tasks that require cognitive flexibility allowing new mental representations benefit from phasic D2 activation (Costa et al. 2014).

\subsection{Apomorphine}

Being a nonselective dopaminergic receptor agonist, apomorphine binds to all dopamine receptors. The binding affinity (K) to D1, D2, D3, D4 and D5 receptors are 101, 32, 26, 2.6 and $10 \mathrm{nM}$ respectively (Vallone et al. 2000; Hsieh et al. 2004).

The pharmaco-therapeutic use of apomorphine has been quite widespread. Its main use is in the treatment of Parkinson's disease and has already been studied in 1951 (Schwab et al. 1951). As it is as well a strong emetic, it should always be given together with antiemetic substances like domperidon. In Parkinsonian patients apomorphine has shown to be able to reverse motor cortical inhibition, suggesting it can modify cortical excitability (Pierantozzi et al. 2001).

\subsection{The aim of this study}

Considering the important role of dopamine in many diseases and also in neuroplasticity, the aim of this project was to further explore the role of dopamine in 
neuroplasticity. In more detail, this thesis aims to examine the influence of the global dopamine agonist apomorphine on non-focal anodal tDCS-induced plasticity. The commonly applied global dopamine agonist L-dopa is being metabolized to norepinephrine, and hence the effects of L-dopa cannot be solely be attributed to the dopaminergic system. Whereas, by using apomorphine only the dopaminergic system will be stimulated. Another problem with L-dopa is, that its effects are phasic, whereas the effects of agonists are tonic, meaning that the agonist binds to its receptor independent of cortical activity. Thus, different effects of L-dopa compared to agonists might be caused not only by activation of different receptor subtypes but also by phasictonic effects. Since apomorphine solves this problem as an agonist, it can answer this question. Nevertheless, it is hypothesized that the effect of apomorphine is similar to Ldopa, in that low and high dosages of apomorphine abolish plasticity, whereas medium dosages reverse non-focal excitatory plasticity, as induced by anodal tDCS, into inhibitory plasticity. 


\section{Material and Methods}

\subsection{Subjects and eligibility criteria}

12 right-handed healthy subjects participated in the experiment (eight males, four females, age $25.75 \pm 3,54$ years (mean \pm SD). Having been thoroughly informed about the study, including the methods of TMS and tDCS, apomorphine and its possible side effects, each subject underwent a medical examination, and gave written informed consent. Exclusion criteria were the following:

1. Cardiac pacemaker or a deep brain stimulator

2. Intracerebral metal implants

3. Age $<18$ or $>40$

4. History of epileptic seizures

5. History of craniocerebral injury with loss of consciousness

6. History of an acute or any chronic medical disease

7. Legal supervision

8. Present pregnancy or lactation period

9. Alcohol, medical or drug dependence as well as any recreational drug use

10. Aphasia

11. Intake of medication that effects the central nervous system. Alcohol intake was not allowed one day before the experiment and on the day of the experiment coffee was not permitted.

12. Participation in a drug or medical device study 8 weeks prior to the experiment The Ethics Committee of the University of Göttingen approved the study (5/7/09). 


\subsection{Monitoring corticospinal excitability with TMS}

In this experiment we recorded the MEP of the right abductor digiti minimi muscle (ADM) with single-pulse TMS, which was generated by a Magstim 200 magnetic stimulator (Magstim Inc., Dyfed, UK) through a figure-eight shaped coil (diameter of one winding $70 \mathrm{~mm}$; peak magnetic field 2,2 tesla) at a frequency of $0.25 \mathrm{~Hz}$ with $5 \%$ variation to avoid expectancy effects. In order to determine the optimal coil position, the coil was moved slowly above the scalp holding it tangentially to the scalp at an $45^{\circ}$ angle to the midsagittal plane with the handle pointing posteriorly and laterally. The site where stimulation resulted in the most consistent and the largest MEP amplitude (hotspot), was marked with a skin-marker. Then the TMS intensity was adjusted to elicit baseline (bl) MEPs of averaged $1 \mathrm{mV}$. The MEPs were recorded from the right ADM with surface electromyography (EMG) Ag-AgCl electrodes attached in a belly-tendon montage. The signals were filtered (30 Hz to $2 \mathrm{kHz}$ ), amplified (Digitimer 360, Digitimer Ltd, Welweyn Garden City, Herts, UK) and then stored on a computer via a Power 1401 data acquisition interface (Cambridge Electronic Design Ltd, Cambridge, UK). The analysis was carried out with Signal Software (Cambridge Electronic Design).

\subsection{Plasticity induction by tDCS}

In this study anodal tDCS was applied using a battery-driven constant current stimulator (NeuroConn) with a maximum output of $4.5 \mathrm{~mA}$. A current strength of $1 \mathrm{~mA}$ was administered for 13 minutes, as previous studies have shown that 13 minutes anodal stimulation is sufficient to induce cortical excitability alterations for about 1 hour. The current was delivered through two saline-soaked surface sponge electrodes each measuring $7 \times 5 \mathrm{~cm}$. The anode was positioned over the motor cortex 
representation area of the right $\mathrm{ADM}$, and the cathode return electrode above the right supraorbital area.

\subsection{Medication with apomorphine}

The participants received either low $(0.1 \mathrm{mg})$, middle $(0.2 \mathrm{mg})$ or high $(0.3 \mathrm{mg})$ dosage of apomorphine or placebo via subcutaneous application ten minutes before the plasticity- inducing protocol. Approximately at this time point apomorphine reaches its highest plasma concentration (LeWitt 2004). We chose $0.3 \mathrm{mg}$ apomorphine as the maximum dosage to avoid frequent systemic side effects. In order to minimize peripheral apomorphine side effects such as a decrease in blood pressure, nausea and vomiting the subjects received $20 \mathrm{mg}$ of the peripheral acting dopaminergic antagonist domperidon three times per day two days before the experiment and two hours before apomorphine application. Grundey et al. (2013) have shown in a control experiment that $20 \mathrm{mg}$ domperidon alone exerts no effect upon motor cortex excitability, thus does not interfere with the experiment.

\subsection{Experimental procedure}

This study was conducted in a double-blinded, randomized and placebo-controlled design. Each subject participated in 4 sessions and each session was separated by an interval of $\geq 1$ week to avoid cumulative drug and stimulation effects.

At the beginning of the experiment the subject was seated on a reclining chair with head and arm support and was asked to relax and to keep the eyes open during the complete course of the experiment. Then the EMG electrodes were placed at the right 
$\mathrm{ADM}$ and the motor cortex representation area of that muscle was determined by TMS. Both spots were marked with a skin marker to ensure constant positioning of the coil and electrodes throughout the session. Having identified the intensity of the TMS stimulus that resulted in MEPs with peak-to-peak amplitudes of on average $1 \mathrm{mV}$, we then started to measure the first baseline, which consisted of 25 MEP. Immediately after the baseline measurements, the participants received either the apomorphine or the placebo (saline) injection. Ten minutes later a second baseline was measured, to control for possible drug-induced changes of MEP amplitudes. If baseline 2 differed from baseline $1(<0.2 \mathrm{mV}$ or $>0.2 \mathrm{mV})$, TMS intensity was adjusted and a third baseline was measured. Then anodal tDCS was applied for 13 minutes. Thereafter, 25 MEPS were recorded every 5 minutes for half an hour, then every 30 minutes for 2 hours, and then again on the same evening, the next morning, the next afternoon and the next evening (Fig. 1).

\begin{tabular}{|c|c|c|c|c|c|}
\hline Premedication & Medication & \multicolumn{2}{|c|}{ Postmedication } & Plasticity & Monitoring motor cortex excitability \\
\hline BL 1 & Placebo & BL 2 & BL 3 & Anodal tDCS & $\begin{array}{l}\text { MEPs every } 5 \text { min for } 30 \mathrm{~min} \text {, then every } \\
30 \text { min until } 2 \text { hours, SE, NM, NA, NE after } \\
\text { intervention }\end{array}$ \\
\hline BL 1 & $\begin{array}{l}0.1 \mathrm{mg} \\
\text { apomorphine }\end{array}$ & BL 2 & BL 3 & Anodal tDCS & $\begin{array}{l}\text { MEPs every } 5 \text { min for } 30 \mathrm{~min} \text {, then every } \\
30 \text { min until } 2 \text { hours, SE, NM, NA, NE after } \\
\text { intervention }\end{array}$ \\
\hline BL 1 & $\begin{array}{l}0.2 \mathrm{mg} \\
\text { apomorphine }\end{array}$ & BL 2 & BL 3 & Anodal tDCS & $\begin{array}{l}\text { MEPs every } 5 \text { min for } 30 \mathrm{~min} \text {, then every } \\
30 \text { min until } 2 \text { hours, } \mathrm{SE}, \mathrm{NM} \text {, NA, NE after } \\
\text { intervention }\end{array}$ \\
\hline BL 1 & $\begin{array}{l}0.3 \mathrm{mg} \\
\text { apomorphine }\end{array}$ & BL 2 & BL 3 & Anodal tDCS & $\begin{array}{l}\text { MEPs every } 5 \text { min for } 30 \mathrm{~min} \text {, then every } \\
30 \text { min until } 2 \text { hours, SE, NM, NA, NE after } \\
\text { intervention }\end{array}$ \\
\hline
\end{tabular}

Time Course

Figure 5. Experimental course of the study

MEPs elicited by single-pulse TMS over the left motor cortical representation area of the right ADM were recorded at 1 mV intensity before drug application (baseline 1 (BL1)). 8 minutes afterwards a second baseline (BL2) was recorded to check for a possible influence of the drug and adjusted if necessary (baseline 3(BL3)). Then anodal tDCS was applied for 13 minutes with a current strength of $1 \mathrm{~mA}$. Immediately after tDCS, MEPs were recorded up to 2 hours and additionally at the same evening (SE), the next morning (NM), next afternoon (NA) and next evening (NE). 


\subsection{Data analysis and statistics}

The individual MEP amplitude means of baselines 1, 2, 3 and the post-stimulation time points were calculated. Post-stimulation MEP amplitudes were normalized to baseline 2 or to baseline 3 if TMS intensity had to be adjusted. The grand averages for each time point per session were calculated by pooling the respective normalized MEP amplitudes. A repeated measure analysis of variance (ANOVA) was performed using MEP amplitude as the dependent variable and medication and time course as withinsubject factors. The Mauchly test of sphericity was performed, and the GreenhouseGeisser correction was applied when necessary. In case of significant results of the ANOVA, exploratory post hoc comparisons were performed using Student's t-tests (paired samples, two-tailed, $\mathrm{p}<0.05$, not corrected for multiple comparisons) between the MEP amplitudes before and after intervention within one experimental condition, and between intervention conditions (medication vs. placebo) within the same time points.

To check for drug influence on cortical excitability, first, second, and third baseline values of the same conditions were compared using Student's t-tests (paired samples, two-tailed, $\mathrm{p}<0.05$, not corrected for multiple comparisons).

To exclude differences between baseline values of different conditions, the respective values were also compared using Student's t-tests (paired samples, two-tailed, $\mathrm{p}<0.05$, not corrected for multiple comparisons).

Additionally, we used a one-way-ANOVA on MEP amplitudes pooled for the first 30 minutes after plasticity induction and normalized to baseline 2 (or 3, if applicable) and Student's t-tests (paired samples, two-tailed, $\mathrm{p}<0.05$, not corrected for multiple comparisons) to compare the first 30 minutes average MEP amplitudes between real substance exposition and respective placebo medication conditions. 


\section{Results}

\subsection{Side effects}

With regard to side effects, after administration of $0.1 \mathrm{mg}$ of apomorphine, 5 out of 12 subjects experienced tiredness, one subject felt slight nausea, one experienced a dry mouth and throat, and one subject complained about itchiness. After administrating the medium dose ( $0.2 \mathrm{mg}$ apomorphine), 8 out of the 12 subjects experienced fatigue, one subject reported a dry mouth and sweating, 4 participants felt nausea and 1 subject vomited. After administration of the highest dose ( $0.3 \mathrm{mg}$ apomorphine), 8 out of the 12 subjects experienced tiredness, 1 hypotension, 5 felt nausea and reported an increase in salivation. Two of these five participants vomited. All symptoms were fully reversible and lasted for about 15 to 45 minutes. No subject experienced any side effect from TMS. From tDCS, however, participants reported mild itching and burning sensations for the first minute of stimulation.

\subsection{Control analysis of baseline-measures}

The average baseline MEP values did not significantly differ between medication conditions, as confirmed by Student's t-tests (paired samples, two tailed, $\mathrm{p}>0.05$ ). Furthermore, apomorphine alone did not have any impact on cortical excitability at any dosage, which is confirmed by Student's t-tests between first and second baseline values (paired samples, two-tailed, $\mathrm{p}>0.05$ ) (Table 1).

\begin{tabular}{|c|c|c|c|c|c|}
\hline $\begin{array}{l}\text { Medication } \\
\text { condition }\end{array}$ & Baseline 1 & Baseline 2 & Baseline 3 & $\begin{array}{l}\text { p-value } \\
\text { BL 1vs } 2\end{array}$ & $\begin{array}{c}\text { p-value } \\
\text { BL 1vs } 3\end{array}$ \\
\hline Placebo & $0.97 \pm 0.12$ & $0.94 \pm 0.21$ & $0.96 \pm 0.14$ & 0.612 & 0.743 \\
\hline $0.1 \mathrm{mg}$ & $1.00 \pm 0.11$ & $1.03 \pm 0.28$ & $1.03 \pm 0.11$ & 0.666 & 0.42 \\
\hline $0.2 \mathrm{mg}$ & $0.99 \pm 0.10$ & $0.87 \pm 0.26$ & $1.01 \pm 0.13$ & 0.148 & 0.458 \\
\hline $0.3 \mathrm{mg}$ & $0.97 \pm 0.10$ & $0.88 \pm 0.54$ & $0.98 \pm 0.09$ & 0.574 & 0.639 \\
\hline
\end{tabular}


b)

\begin{tabular}{l|c|l|c}
\hline $\begin{array}{l}\text { Medication } \\
\text { condition }\end{array}$ & Baseline 1/2 & Baseline 3 & $\begin{array}{c}\text { p-value } \\
\text { BL 1/2 vs. 3 }\end{array}$ \\
\hline Placebo & $48.92 \pm 10.35$ & $49.00 \pm 10.20$ & 0.071 \\
$0.1 \mathrm{mg}$ & $48.75 \pm 8.95$ & $49.42 \pm 9.12$ & 0.674 \\
$0.2 \mathrm{mg}$ & $48.17 \pm 9.13$ & $49.25 \pm 9.50$ & 0.151 \\
$0.3 \mathrm{mg}$ & $47.08 \pm 7.61$ & $47.75 \pm 7.52$ & 0.255 \\
\hline
\end{tabular}

Table 1: Descriptive Statistics of a) Baseline MEPs and b) Stimulation intensity

The means of the baseline MEPs and standard deviations are shown for baseline 1, 2 and 3. They did not significantly differ across medication conditions, as tested with Student's t-tests. Stimulation intensity, as measured by percentage of maximum stimulator output (\%MSO), mean and standard deviation for baseline 1 and 2 accordingly and baseline 3 are shown. Student's t- tests show that these also did not differ across medication conditions.

\subsection{Effect of apomorphine on anodal tDCS-induced plasticity}

MEPs in the placebo medication condition were significantly enhanced for 30 minutes after anodal tDCS. After administration of apomorphine, MEP values did not significantly differ from baseline values, except in minute 0 where excitatory plasticity was significantly reduced (Figure 2). This suggests that anodal tDCS-induced aftereffects were abolished or reduced by all doses of apomorphine.

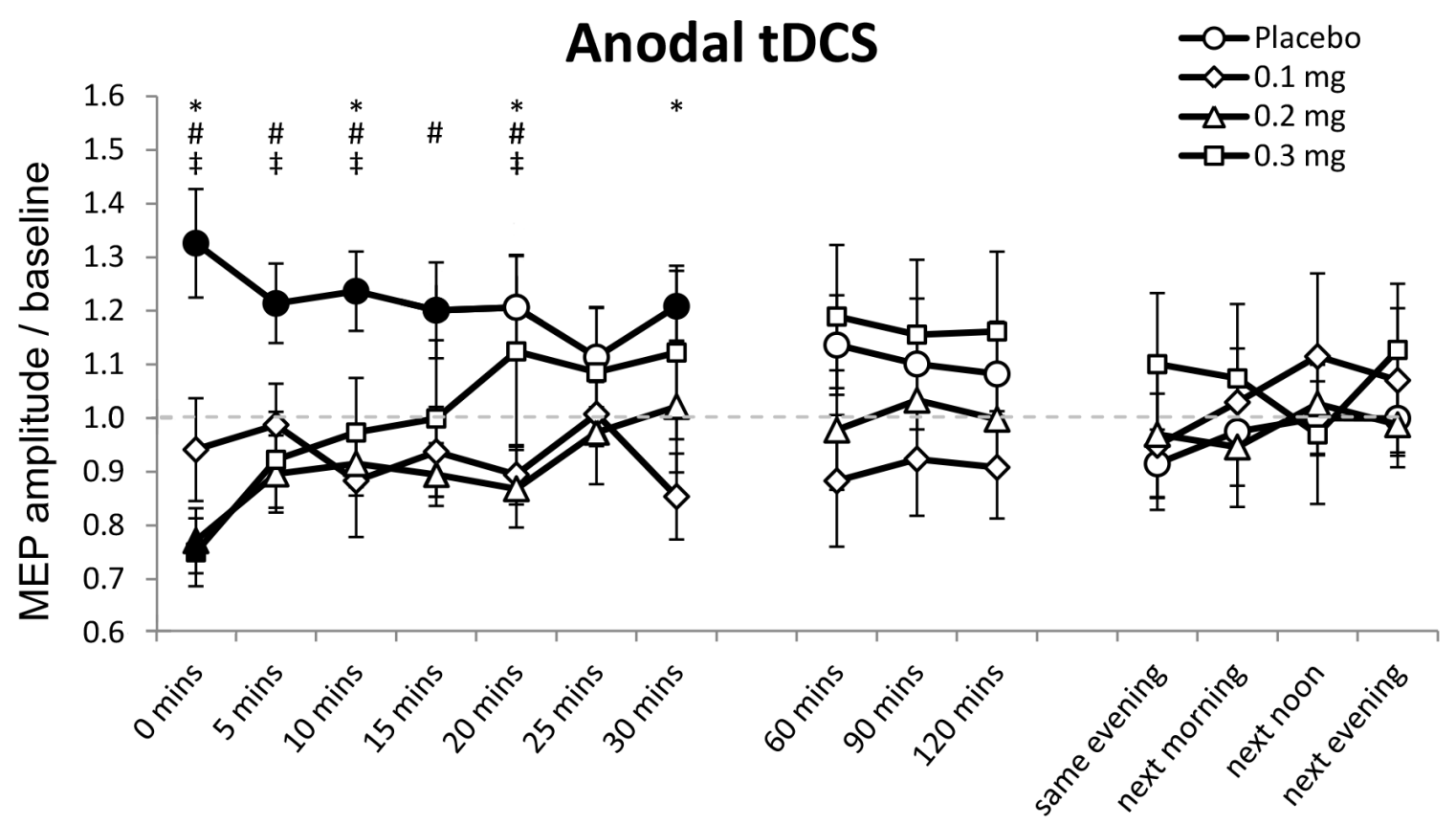

Figure 6. Time course of the MEP values after tDCS stimulation 
The $\mathrm{x}$-axis displays the time points in minutes after anodal tDCS. The y-axis shows the MEP amplitudes, which were standardized to the corresponding baseline values. Error bars indicate standard error of the mean (SEM). The graph illustrates that anodal tDCS induces an excitability increase lasting for about 30 minutes. Low dose $(0.1 \mathrm{mg})$, medium dose $(0.2 \mathrm{mg})$ and high dose $(0.3 \mathrm{mg})$ of apomorphine impaired and abolished the after effects of anodal tDCS. After 60 minutes there were no significant effects anymore. The filled symbols indicate statistically significant deviations of the post-tDCS MEP values compared with baseline. The asterisks indicate significant differences between ${ }^{*}$ placebo vs. 0.1, \# placebo vs. 0.2 , ₹ placebo vs. 0.3 .

A repeated measures analysis of variance (RM ANOVA) was calculated with the factors medication condition (4 levels: placebo, $0.1 \mathrm{mg}$ apomorphine, $0.2 \mathrm{mg}$ apomorphine, 0.3 mg apomorphine ) and time (15 levels: $0 \mathrm{~min}, 5 \mathrm{~min}, 10 \mathrm{~min}, 15 \mathrm{~min}, 20 \mathrm{~min}, 25 \mathrm{~min}, 30$ min, $60 \mathrm{~min}$, $90 \mathrm{~min}, 120 \mathrm{~min}$, same evening, next morning, next noon, next evening after tDCS). The RM ANOVA confirmed a significant interaction of medication condition $\mathrm{x}$ time $(\mathrm{F}(42)=2.035 ; \mathrm{p}<0.001)($ table 2$)$.

\begin{tabular}{|l|r|r|r|}
\hline \multicolumn{1}{|c|}{ Source } & df & \multicolumn{1}{c|}{$\mathrm{F}$} & \multicolumn{1}{c|}{ Sig. } \\
\hline $\begin{array}{l}\text { Medication } \\
\text { Condition }\end{array}$ & 3 & 1.309 & .288 \\
\hline Time & 14 & .429 & .963 \\
\hline $\begin{array}{l}\text { Medication } \\
\text { Condition } \mathrm{x} \\
\text { Time }\end{array}$ & 42 & 2.035 & $<.0001$ \\
\hline
\end{tabular}

Table 2: RM ANOVA of medication condition, time and medication condition $x$ time

This table shows degrees of freedom (dF), F-statistics (F) and p-values (Sig.) of medication condition, Time and Medication Condition x Time. The main effects of medication condition and time were not significant. However, there is a significant interaction between medication condition $\mathrm{x}$ time.

Post-hoc Student's t-tests showed that MEP amplitudes in the placebo condition were significantly larger than baseline between 0 - 15 min and 30 minutes after anodal tDCS $(\mathrm{p}<0.05)$. Furthermore under medium and high dose apomorphine MEPs were reduced significantly immediately after stimulation $(\mathrm{p}=0.0001$ and $\mathrm{p}=0.002$ respectively). The remaining MEP amplitudes under low, medium and high dose apomorphine did not significantly differ from baseline values at any time point $(\mathrm{p}>0.05)$.

For the effects of different dosages of apomorphine on anodal tDCS-induced 
plasticity with regard to the grand average calculated for the first $30 \mathrm{~min}$ after intervention, the one-way ANOVA followed by exploratory Students t-test revealed differences between all drug and the respective placebo conditions: all doses of apomorphine had a similar abolishing effect on anodal tDCS-induced facilitatory plasticity, which was significant for small and medium dosages $(p=0.009, p=0.001$ and $\mathrm{p}=0.151$ for $0.1 \mathrm{mg}, 0.2 \mathrm{mg}$ and $0.3 \mathrm{mg}$ vs. placebo respectively).

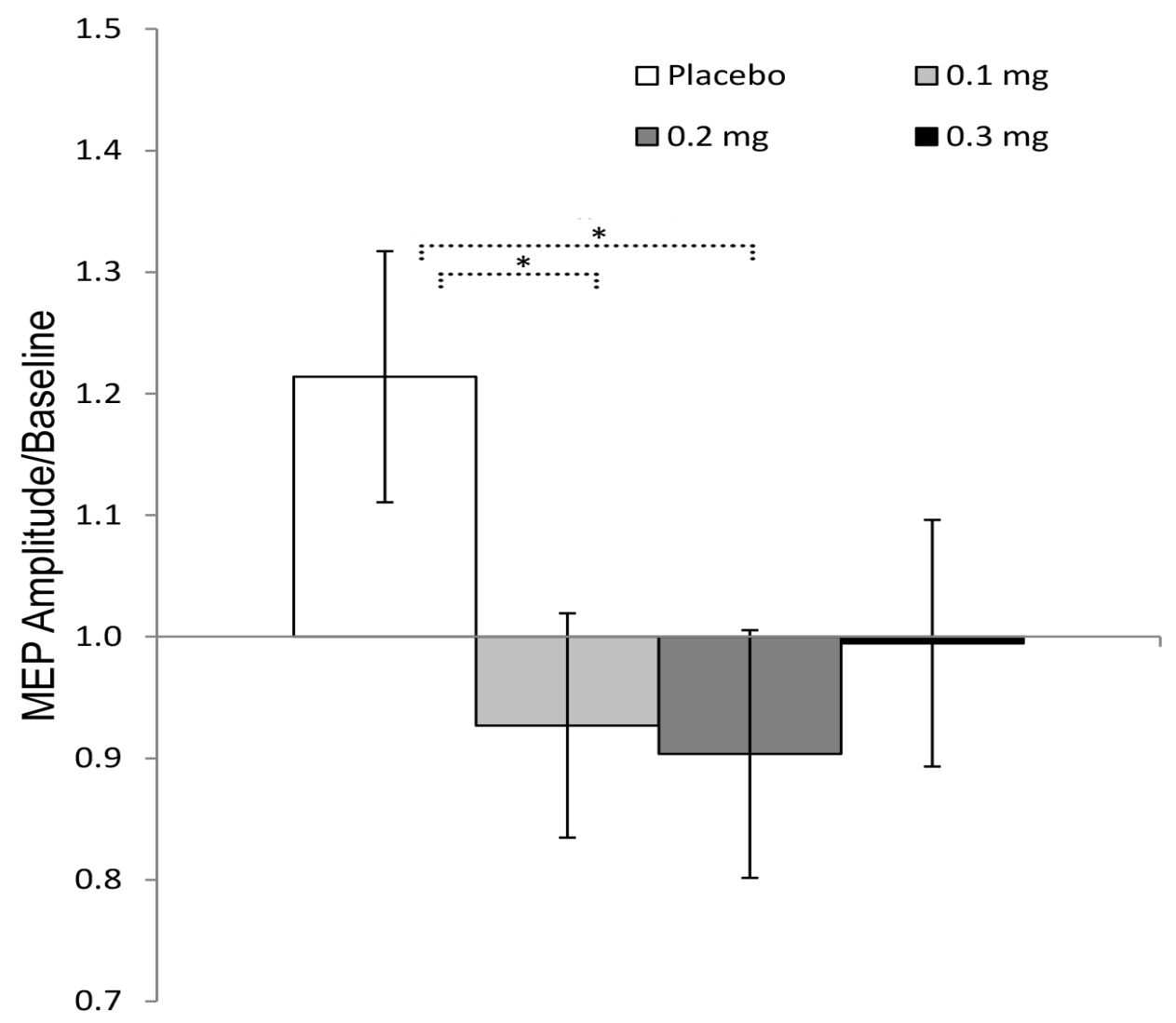

Figure 7. Bar charts of average normalized MEP of $30 \mathrm{~min}$ after tDCS

Anodal tDCS alone (placebo medication condition) leads to a significant increase of MEP, anodal tDCS combined with all dosages of apomorphine show a decrease of pooled MEP values, which is significant ( $p$ $<0.05$ ) in comparison to the placebo medication condition for small and medium dosages. Error bars indicate SEM. ${ }^{*}=\mathrm{p}<0.05$ 


\section{Discussion}

In this experiment, anodal tDCS under placebo medication induced LTP-like plasticity, which was, however, abolished by apomorphine independent from dosage.

\subsection{Anodal tDCS combined with placebo medication}

In the placebo medication condition, anodal tDCS over the primary motor cortex induced a significant increase in cortico-spinal excitability. These after-effects lasted for about 30 minutes in accordance with foregoing studies (Nitsche and Paulus 2000; Nitsche and Paulus 2001; Nitsche et al. 2008).

\subsection{Anodal tDCS with apomorphine condition}

Increasing dopamine receptor activation by apomorphine abolished the excitability enhancement elicited by anodal tDCS in this study with all dosages applied.

$0.1 \mathrm{mg}, 0.2 \mathrm{mg}$ and $0.3 \mathrm{mg}$ of apomorphine are all equivalent to low dosage of other dopamine agonists, because in Parkinsonian patients it has been postulated that for diagnostic testing $1.5-4.5 \mathrm{mg}$ apomorphine is equal to a dosage of $250 \mathrm{mg} \mathrm{L}$-dopa (Koller and Stacy 2004). Hence $0.1-0.3 \mathrm{mg}$ apomorphine can be compared roughly to 25 mg L-dopa.

Consequently, the result from the current study is in line with previous research that showed that a low dose of L-dopa abolishes facilitatory as well as inhibitory plasticity, where $25 \mathrm{mg}$ of L-dopa abolished after-effects of tDCS and diminished PASinduced excitability changes (Monte-Silva et al. 2010; Thirugnanasambandam et al. 2011). 
Stimulating D1, D2 or D2/ D3 receptors with low dose dopamine agonists, which have been related to $25 \mathrm{mg}$ low dose L-dopa, also reduces tDCS-induced plasticity (Monte-Silva et al. 2009; Fresnoza et al. 2014a; Fresnoza et al. 2014b). For instance low doses of ropinirole, a D2/D3 dopamine agonist, impair tDCS- and PAS-induced aftereffects (Monte-Silva et al. 2009) as do low doses of bromocriptine, a selective D2 agonist (Fresnoza et al. 2014a). For predominant D1 receptor activation by block of D2 receptors during simultaneous application of L-dopa, Fresnoza et al. (2014b) showed also that anodal tDCS-induced plasticity is impaired under low dosage.

Not only compared to L-dopa and other dopaminergic substances, the apomorphine dosages applied in the present study are equivalent to low doses, but also when compared to the range of apomorphine dosages. Even the highest dose of $0.3 \mathrm{mg}$ is quite low when compared to $4 \mathrm{mg}$, the average dose for Parkinson patients during a hypokinetic period (Stacy 2004). Since Parkinsonian patients have a lack of dopamine it is not appropriate to compare their dosage to healthy participants without dopaminergic deficits. Nevertheless, also comparing the dosages to other studies it becomes clear that these are low doses. Examining the effect of apomorphine on cognition, $0.005 \mathrm{mg} / \mathrm{kg}$ was used as a low dose, which would equal to $0.3 \mathrm{mg}$ in a $60 \mathrm{~kg}$ person, which was the highest dose used in our study (Friston et al. 1992; Montoya et al. 2008).

Although apomorphine is a global dopamine receptor agonist, it is thought that low doses of apomorphine (i.e., $\sim 0.004 \mathrm{mg} / \mathrm{kg}$ ) mainly stimulate presynaptic dopamine receptors (Di Chiara et al. 1976; Yamada and Furukawa 1980; LeWitt 2004; Montoya et al. 2008; Schellekens et al. 2010; Passamonti et al. 2013). Presynaptic receptors serve as autoreceptors, which are regulatory receptors that modulate membrane excitability and influence the synthesis and metabolism of dopamine, hence controlling dopamine 
release and reuptake (Schmitz et al. 2003). They belong to the D2 family, which is coupled with inhibitory G-proteins, therefore suppressing adenyl cyclase and thus inhibiting dopaminergic neurons (Wolf and Roth 1990; Usiello et al. 2000; Centonze et al. 2003). Consequently, by binding at presynaptic receptors, dopamine activates a negative feedback mechanism, in which the presynapse is hyperpolarized and less dopamine is synthesized and released (Benoit-Marand et al. 2001). Hence the extracellular dopamine concentration is reduced and the firing rate of the dopaminergic neurons is decreased (Schmitz et al. 2003). In line with this, it has been shown that D2like autoreceptor activation by pergolide might cause impaired learning in humans (Breitenstein et al. 2006). This activation of dopaminergic autoreceptors by relatively low-dose apomorphine is therefore a possible explanation for the results of the present study. Animal studies support this hypothesis, as it was also shown in rats that low doses of apomorphine preferentially activate D2 autoreceptors and inhibit dopaminergic neurons, thus suppressing locomotor behavior; whereas higher doses activate post-synaptic receptors and have an enhancing effect on memory consolidation (Carrera et al. 2011). Human cognition studies show a similar effect. Administration of $0.005 \mathrm{mg} / \mathrm{kg}$ apomorphine s.c. decreased cognitive performance in healthy subjects (Schellekens et al. 2009; Schellekens et al. 2010). The authors suggested that apomorphine leads to activation of presynaptic dopamine receptors and subsequently a decrease in dopamine neurotransmission, as the effect was more severe in participants with poor baseline performance, presumably due to a lower level of prefrontal dopamine functioning. However, one has to state that this explanation of our result is speculative at present.

As explained in the introduction, tDCS-induced plasticity depends on NMDA receptors and thus glutmatergic synapses as well as reduction of GABAergic activity and 
that they are calcium channel dependent (Nitsche et al. 2003b; Nitsche et al. 2004; Fritsch et al. 2010; Stagg et al. 2011). Consequently it is likely, albeit speculative, that those systems are relevant for the results of the present study. In accordance with this hypothesis, Momiyama (et al. 1996) have shown that activation of presynaptic dopamine receptors reduce excitatory glutamatergic transmission, which might be mediated through a cAMP-dependent pathway resulting in a reduction of calcium influx into the glutamatergic synapse (Momiyama et al. 1996). Nitsche et al. (2003b) have shown the calcium dependence of tDCS. Since formation of LTP is prevented if the intracellular calcium concentration is too low (Lisman 2001), it can be argued that low dosages of apomorphine activate autoreceptors that through different pathways lead to a reduction of calcium influx and thus LTP formation (Momiyama et al. 1996).

Some potential limitations of this study should be considered. Firstly, the results of apomorphine effects on cathodal tDCS as well as PAS-induced focal plasticity are lacking a more complete picture of the effects of apomorphine on human motor cortex plasticity. Respective experiments are still ongoing.

Secondly, CNS active drugs such as apomorphine can alter attention and vigilance and thus contribute to the observed drug effects on TMS measures (Ziemann et al. 2015). Since apomorphine induced relevant side effects, especially tiredness and nausea, the plasticity abolishing effect could be at least partially explained by those side effects. However, to control for a drug effect on attention and vigilance we measured a second baseline 10 minutes after injecting apomorphine. At this time the plasma level of apomorphine is maximal. The Student's t-test comparing first, second and third baseline values did not show significant excitability differences, thus suggesting that apomorphine alone did not influence cortical excitability at any dosage. Furthermore, 
other studies have shown that lorazepam, which as well causes tiredness, did also not relevantly alter tDCS effects (Nitsche et al. 2004).

Thirdly, due to differences in body weight, as well as various genetic polymorphisms of proteins involved in regulating, for instance, dopamine transport or uptake, a significant inter-individual variability of the drug effects on blood concentration and hence cortical plasticity might exist (Moreau et al. 2015; Uno et al. 2015; Ziemann et al. 2015). A limitation could be that blood concentration of apomorphine was not measured.

Fourthly, Wiethoff et al. (2014) have shown that even though anodal tDCS facilitates MEPs, there is a relevant inter-individual variability in the response to tDCS. However they used a stimulation intensity of $2 \mathrm{~mA}$, whose effect differs from $1 \mathrm{~mA}$ protocols (Batsikadze et al. 2013). Also, anatomical differences might account for interindividual variability of tDCS-induced plasticity (Datta et al. 2012). Despite those interindividual differences, we could, however, show that in the placebo medication condition anodal tDCS induces a significant increase in motor cortex excitability.

The results of this study furthermore confirm the narrow range in which dopamine receptors work optimally and how important consideration of this is when treating patients with diseases affecting the dopaminergic system. Therefore further research is very important to examine the influence of dopamine on neuroplasticity, especially apomorphine, as there are little studies so far using this substance. It would be of great interest to examine the influence of higher doses of apomorphine on tDCS- as well as PAS-induced plasticity. Furthermore it would be interesting to examine the effect of apomorphine on plasticity in Parkinsonian patients, as they are deprived of dopamine and the increase of it might have a different effect than in healthy subjects. 


\section{Summary}

The aim of this thesis was to study the effect of apomorphine on non-focal anodal tDCSinduced plasticity and thus further examine the influence of the dopaminergic system on motor cortex plasticity in humans. In a randomized double blind study design, 12 healthy subjects received in four different sessions intracutaneous injections of placebo or $0.1,0.2,0.3 \mathrm{mg}$ of apomorphine, a global dopamine agonist, while the effect of anodal tDCS-induced motor cortical plasticity was examined. In accordance with previous research, in the placebo medication condition cortical excitability was significantly enhanced by anodal tDCS. For all dosages of apomorphine explored in the present experiment, anodal tDCS-induced plasticity effects were abolished. $0.1,0.2$, and $0.3 \mathrm{mg}$ apomorphine are comparable to low doses of other dopamine agents, such as L-dopa. Hence, those findings are in line with previous research showing that low doses of dopamine lead to an abolishment of plasticity induction. Low doses of apomorphine (i.e. $\sim 0.004 \mathrm{mg} / \mathrm{kg}$ ) are assumed to mainly stimulate presynaptic dopamine receptors, whose activation leads to a decrease in dopamine neurotransmission through negative feedback mechanisms and thus to a reduction in dopaminergic firing rate. As the activation of presynaptic dopamine receptors reduce excitatory glutamatergic transmission, this can explain why apomorphine abolished the anodal tDCS effect.

However, some questions remain to be explored, for instance the influence of higher doses of apomorphine on tDCS-induced plasticity and consequently more research is needed to fully understand the role of dopamine in neuroplasticity. 


\section{Attachments}

\subsection{Subject information sheet}

\section{UNIVERSITÄTSMEDIZIN :
GÖTTINGEN :}

Universitätsmedizin Göttingen, D-37099 Götinge
Zentrum Neurologische Medizin. Abteilung Kliniss

Zentrum Neurologische Medizin Abteilung Klinische Neurophysiologie Direktor: Prof. Dr. W. Paulus

D-37099 Göttingen Briefpost Robert-Koch-Straße 40, D-37075 Gottingen Adresse +49 (0)55139- 6650/ 6652 Telefon $+49(0) 55139-8126 \mathrm{Fax}$ mkurze@med.uni-goettingen.de E-Mail

$+49(0) 55139-6710$ Telefon Neurologische Station $+49(0) 55139-6710$ Telefor Neurologische Station
+49 (0) $55139-10363$ Telefon Epilepsie-Monitoring-Einheit $+49(0) 55139-13669 \mathrm{Fax}$

Spezialambulanzen

$$
\begin{aligned}
& \text { Epilepsie . } \\
& \text { E }
\end{aligned}
$$

Bewegungsstorlepsie

Kopsschmerzen

Schwindel:

+49 (0)551 39 - 8484 Terminvergabe

Neuromuskulare Erkrankungen -

+ +49 (0)551 59 - 6652 Terminvergabe

PD.MN/Ku Aktenzeichen

Informationsschrift für Teilnehmer über die wissenschaftliche Studie:

Dopaminerge Modulation von Neuroplastizität beim Menschen:

Neurophysiologische Basis und behaviorale Auswirkungen (tDCS,

Apomorphin), Version 1-1, 01.06.2011

Sehr geehrte Damen, sehr geehrte Herren!

Wir bedanken uns für Ihr Interesse an der o.g. Studie und möchten Ihnen die Studie anhand dieses Informationsbogens erläutern.

\section{Ziel}

Dopamin ist ein wichtiger Botenstoff im menschlichen Gehirn, der die Kommunikation zwischen Nervenzellen beeinfußt. Die Kommunikation zwischen Nervenzellen, die über ihre Verbindungen miteinander gewährleistet wird, ist eine wesentliche Grundlage für die Steuerung des Denkens und Verhaltens. Insbesondere während Lernvorgängen kommt es hierbei zu Veränderungen der Stärke der Verbindungen zwischen den Nervenzellen: Die Verbindungen von Nervenzellen, die wichtig für das Lernen einer bestimmten Aufgabe sind, werden gestärkt, wohingegen irrelevante Verbindungen geschwächt werden. Auch für diese Vorgänge spielt Dopamin eine wichtige Rolle. Wir wollen in dieser Untersuchung untersuchen, welche spezifische $1 / 8$ Funktion das Dopamin bei der Stärkung und Schwächung der Verbindungen zwischen Nervenzellen hat. Hierfür werden wir ein Hirnstimulationsverfahren 


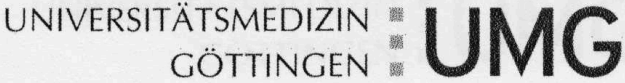

einsetzen, das mittels über der Kopfhaut angewendeten schwachen Gleichstroms (transkranielle Gleichstromstimulation) in der Lage ist, die Stärke der Verbindungen zwischen Nervenzellen vorübergehend zu verändern. Um den Einfluß des Dopamins auf die Verbindungsstärke zu überprüfen, wird zusätzlich die Substanz Apomorphin gegeben, die ähnliche Wirkungen wie das Dopamin selbst hat, oder ein ScheinMedikament (Placebo). Mit der transkraniellen Gleichstromstimulation werden in dieser Untersuchung die Verbindungsstärken von Nervenzellen über dem Gebiet der Hirnrinde verändert, die für die Durchführung von Bewegungen wichtig ist.

Veränderungen der Verbindungsstärke zwischen den Nervenzellen werden durch ein anderes Stimulationsverfahren, die transkranielle Magnetstimulation, erfasst. Hierbei wird über dem Gebiet der Hirnrinde, das für Bewegungen zuständig ist, ein kurzer starker Magnetpuls gegeben. Dieser erzeugt einen elektrischen Stromfluß in der Hirnrinde, der wiederum Nervenzellen aktiviert. Ist die Aktivierung genügend stark, wird der Impuls zu einem Handmuskel weitergeleitet, und es entsteht ein Muskelzucken, dessen Stärke durch Elektroden, die auf der Haut platziert sind, erfasst werden kann. Dieses stellt ein Maß für die Verbindungsstärke zwischen den Nervenzellen dar.

Die Ergebnisse dieser Untersuchung werden unsere Kenntnisse bezüglich der Funktionen des Botenstoffes Dopamins bei der Stärkung und Schwächung von Nervenzellverbindungen in der menschlichen Hirnrinde wesentlich erweitern. Dieses ist wichtig, um die Funktionsweise des gesunden menschlichen Gehirns besser zu verstehen. Da Veränderungen der Verbindungsstärke zwischen Nervenzellen wesentliche Bedeutung für das Denken und Verhalten von Menschen haben, können diese Ergebnisse zukünftig dazu beitragen, auch diese Funktionen besser zu verstehen.

\section{Verlauf}

Diese Studie umfaßt 8 Sitzungen, von jeweils etwa 2,5 Stunden Dauer, die jeweils wie folgt ablaufen: Ab dem zweiten Tag vor der eigentlichen Untersuchung und am Untersuchungstag selbst nehmen Sie jeweils dreimal täglich die Substanz Domperidon ein. Diese Substanz soll verhindern, dass das Apomorphin außerhalb des Gehirns wirksam ist, um Nebenwirkungen des Apomorphins zu verhindern. Am Untersuchungstag selbst kommt zunächst die transkranielle Magnetstimulation zur Anwendung. Hierbei wird eine Reizspule auf Ihrem Kopf aufgelegt, die einen kurzen 


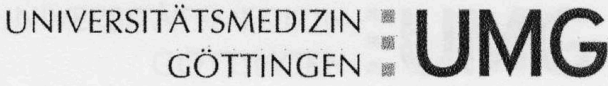

und starken magnetischen Puls erzeugt, der wiederum einen elektrischen Stromfluß in der Hirnrinde erzeugt, der zur Entladung von Nervenzellen führt. Wir werden diesen Magnetimpuls über dem Gebiet der Hirnrinde geben, das für die Bewegungssteuerung eines Muskels des kleinen Fingers zuständig ist. Der Magnetreiz wird stark genug sein, um eine Zuckung des Fingers auszulösen. Die Stärke dieser Zuckung wird über Elektroden über dem Muskel erfasst, die auf der Haut angebracht sind. Wir werden die Intensität der Stimulation bestimmen, die zu einer Zuckung mittlerer Stärke führt. Es werden dann 20 Magnetpulse gegeben und aufgezeichnet. Daraufhin wird die Substanz Apomorphin bzw. eine PlaceboSubstanz (eine Placebo-Substanz ist hierbei eine Substanz, die keine Wirkung hat) mit einer kleinen Spritze unter die Bauchhaut gespritzt. 10 Minuten später werden erneut 20 Magnetimpulse gegeben. Daraufhin erfolgt die Stimulation mit schwachem Gleichstrom. Hierzu werden befeuchtete Schwämmchen auf der Kopfhaut mit Gummibändern befestigt. Eines der Schwämmchen wird über der Stelle der Kopfhaut befestigt, über dem der Magnetstimulus gegeben wurde, ein anderes Schwämmchen an der Stirn. Es fließt nun für 9 oder 13 Minuten ein schwacher Gleichstrom. Daraufhin werden wiederum 20 Magnetimpulse gegeben, in der ersten halben Stunde alle 5 Minuten, dann alle 30 Minuten bis zu 2 Stunden nach der Gleichstromstimulation, nochmals am selben Abend sowie morgens, mittags und abends am nächsten Tag. Um eine konstante Position der Magnetspule und der Finger-Elektroden zu gewährleisten, werden deren Positionen mit wasserfesten Stiften markiert. Zwischen den einzelnen Sitzungen ist ein Mindestabstand von einer Woche einzuhalten.

Sie können, ohne dass Ihnen hieraus Nachteile erwachsen, jederzeit ohne Angaben von Gründen Ihre Einwilligung zur Studienteilnahme widerrufen und die Datennutzung widerrufen, bzw. die Löschung Ihrer Daten verlangen.

\section{Risiken}

Die transkranielle Magnetstimulation ist eine nicht-invasive und schmerzfreie Untersuchungsmethode. Die bereits vorliegenden, umfangreichen Erfahrungen haben gezeigt, daß dieses Verfahren risiko- und nebenwirkungsarm ist, wenn die Ausschlußkriterien beachtet werden (siehe unten). In seltenen Fällen ist mit Auftreten ${ }^{3 / 8}$ von Müdigkeit und Kopfschmerzen zu rechnen. 


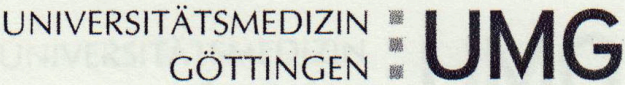

Die transkranielle Gleichstromstimulation ist ein ebenfalls nicht invasives und schmerzfreie Verfahren, das bereits in einer Vielzahl von Untersuchungen angewendet worden ist und sich als risiko- und nebenwirkungsarm erwiesen hat. Selten und lediglich nach kontinuierlicher Gleichstromapplikation über Stunden traten leichte Kopfschmerzen und Hautreizungen im Bereich der Elektroden auf, die relativ schnell vollständig reversibel waren. Während der Stimulation kann es zu einem Gefühl des Juckens oder Kribbelns unter den Elektroden kommen.

Durch die Substanzen Apomorphin und Domperidon kann es zu folgenden Nebenwirkungen kommen:

Apomorphin: in über $10 \%$ der Fälle kann es zu Verhärtungen des Gewebes an der Stelle kommen, an der die Substanz unter die Haut gespritzt wird. In über $1 \%$ der Fälle kann es zu Übelkeit und Erbrechen, des weiteren zu Schläfrigkeit, Verwirrtheit und Trugwahrnehmungen kommen. Mit einer Häufigkeit von 0,1\% können ein Blutdruckabfall, unkontrollierbare Bewegungen, Atemstörungen und Veränderungen des Blutes auftreten. Gesteigerte Geschlechtslust und Spielsucht können ebenfalls auftreten, über deren Häufigkeit sind allerdings keine genauen Angaben möglich. Domperidon: in 0,01\% können Magen-Darm-Beschwerden, Brustdrüsenvergrößerung beim Mann, Milchfluß aus der Brust und Regelstörungen bei der Frau auftreten. In 0,001\% können Überempfindlichkeitsreaktionen mit Hautjucken und -schwellungen, Bewegungsstörungen und eine Erhöhung der Substanz Prolaktin im Blut, die für die Milchbildung in der Brustdrüse verantwortlich ist, auftreten. Durchfall und Appetitstörungen können auftreten, hier ist allerdings zur Häufigkeit nichts bekannt.

Falls Nebenwirkungen auftreten, wird jeder Proband bis zu deren Verschwinden bzw. deren Klärung entsprechend ärztlich behandelt und beobachtet. Sollten ernste Komplikationen auftreten, erhält der Proband eine Therapie durch einen Spezialisten.

\section{Ausschlusskriterien für die Teilnahme an der Studie}

Falls einer der folgenden Punkte auf Sie zutrifft, ist eine Teilnahme an der Studie nicht möglich:

1. Herzschrittmacher, Tiefe Hirnstimulation

2. Intrazerebrale Metallimplantate (z.B. Clips nach Operation eines intrazerebralen Aneurysmas, Implantation einer künstlichen Kochlea) 


\section{UNIVERSITÄTSMEDIZIN
GÖTTINGEN}

3. Alter $<18$ oder $>40$ Jahre.

4. Hinweise auf epileptische Anfälle in der Vorgeschichte.

5. Schädelhirntrauma mit Bewusstseinsverlust in der Vorgeschichte

6. Vorliegen einer gravierenden internistischen Erkrankung oder Vorliegen einer psychiatrischen Erkrankung mit Einschränkung der Urteilsfähigkeit

7. Vorliegen einer gesetzlichen Betreuung

8. Schwangerschaft oder Stillperiode

9. Alkohol-, Medikamenten- und Drogenabhängigkeit

10. Rezeptive oder globale Aphasie (Störung des Sprachverständnisses bzw. zusätzlich des Sprechens)

11. aktuelle oder chronische zentralnervös wirksame Medikation

12. Teilnahme an einer klinischen Arzneimittel- oder Medizinprodukte--

Prüfung innerhalb der letzten 8 Wochen

Sie können, ohne dass Ihnen hieraus Nachteile erwachsen, jederzeit ohne Angaben von Gründen Ihre Einwilligung zur Studienteilnahme widerrufen und die Datennutzung widerrufen, bzw. die Löschung Ihrer Daten verlangen.

\section{Schwangerschaft und Stillzeit}

Wir weisen nochmals darauf hin, dass schwangere Frauen an dieser Studie nicht teilnehmen dürfen. Zu Beginn der klinischen Prüfung müssen sich deshalb alle Frauen einem Schwangerschaftstest unterziehen. Davon ausgenommen sind Frauen nach den Wechseljahren oder solche, die operativ sterilisiert wurden. Durch einen Schwangerschaftstest kann jedoch eine Schwangerschaft erst einige Tage nach der Empfängnis verlässlich nachgewiesen werden. Im Falle Ihrer Teilnahme an dieser Studie müssen Sie zuverlässige Maßnahmen der Schwangerschaftsverhütung anwenden. Diese sind abstinentes Verhalten oder die Verwendung zweier zuverlässiger Verhütungsmethoden, beispielsweise die Pille und ein Kondom. Der Grund dafür ist, dass für Domperidon aus Tierversuchen Hinweise für ein erhöhtes Risiko einer Schädigung des ungeborenen Lebens vorliegen, und es bislang nicht geklärt ist, ob Apomorphin zu einer schädigung des Ungeborenen führen kann, wenn ${ }^{5 / 8}$ es während der Schwangerschaft eingenommen wird. 


\section{UNIVERSITÄTSMEDIZIN $:$
GÖTTINGEN}

Sollten Sie während der Studie schwanger werden oder den Verdacht haben, dass Sie schwanger geworden sind, müssen Sie umgehend den Studienarzt informieren. Auch stillende Frauen dürfen an dieser Studie nicht teilnehmen, da Domperidon und Apomorphin mit der Muttermilch in den Körper des Kindes gelangen und zu seiner Schädigung führen könnten.

Persönlicher Nutzen der Teilnahme an der Studie

Sie werden durch die Teilnahme an dieser Studie außer einer ärztlichen

Untersuchung voraussichtlich keinen persönlichen Gesundheitsnutzen haben. Es handelt sich um eine Studie aus dem Bereich der Grundlagenwissenschaften, die zum besseren Verständnis der Auswirkungen des Dopamins auf die Verbindungsstärken zwischen Nervenzellen dient.

\section{Datenschutz}

Die personenbezogenen Daten werden in Papierform und elektronisch auf einem Laborcomputer der Abteilung Klinische Neurophysiologie erhoben und gespeichert. Auf die Daten haben ausschließlich die Studienärzte Zugriff. Die Daten werden 15 Jahre nach Erhebung gespeichert, werden an keine weiteren Institutionen oder Personen mit Ausnahme der Studienärzte weitergegeben und werden auf Anfrage bei Widerruf der Studienteilnahme gelöscht. Die Datennutzung erfolgt pseudonymisiert. Dieses bedeutet, dass die Daten ohne Namensnennung mit Nummern kodiert erfolgt. Die Zuordnung der Daten zu einer Person ist nur möglich, wenn hierfür der Schlüssel eingesetzt wurde, mit denen die Daten pseudonymisiert wurden. Die personenbezogenen Daten werden unter besonderen Schutzvorkehrungen getrennt von den pseudonymisierten Daten aufbewahrt. Eine Entschlüsselung ist nur such die verantwortlichen Studienärzte Möglich. Dritte erhalten keinen Einblick in die Originalunterlagen. Es ist beabsichtigt, die Ergebnisse dieser Studie zu publizieren. Hierfür werden die Daten anonymisiert verwendet.

\section{Aufwandsentschädigung}

Für Ihre Teilnahme an dieser Studie erhalten Sie eine Aufwandsentschädigung von $300 €$, wenn Sie an allen Terminen der Studie teilnehmen. Sollten Sie die Einwilligung zur Teilnahme an der Studie widerrufen, erfolgt die 


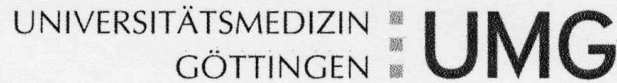

\section{Versicherung}

Bei der Durchführung der wissenschaftlichen Studie sind alle Studienteilnehmer versichert. Der Umfang des Versicherungsschutzes ergibt sich aus den Versicherungsunterlagen, die Sie auf Wunsch ausgehändigt bekommen. Wenn Sie vermuten, dass durch die Teilnahme an der Studie Ihre Gesundheit geschädigt oder bestehende Leiden verstärkt wurden, müssen Sie dies unverzüglich dem Versicherer

Allianz Versicherungs-Aktiengesellschaft

Königinstraße 28

80802 München

Telefon: 08938000

Fax: 089349941

Versicherungsnummer AS-9100357014

direkt anzeigen, ggf. mit Unterstützung durch Ihren Studienarzt, um Ihren Versicherungsschutz nicht zu gefährden. Sofern Ihr Arzt Sie dabei unterstützt, erhalten Sie eine Kopie der Meldung. Sofern Ihre Anzeige direkt an den Versicherer geht, informieren Sie bitte zusätzlich Ihren Studienarzt. Bei der Aufklärung der Ursache oder des Umfangs eines Schadens müssen Sie mitwirken und alles unternehmen, um den Schaden abzuwenden oder zu mindern. Sie erhalten auf Wunsch ein Exemplar der Versicherungsbestätigung einschließlich der Versicherungsbedingungen. Wir weisen Sie insbesondere auf 1.4 (zu den Ausschlüssen), 3. (zum Umfang der Leistungen) und 4.3 (zu Ihren Obliegenheiten) hin. 


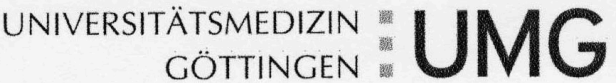

Prof. Dr. med. Michael Nitsche

Oberarzt der Abteilung

Klinische Neurophysiologie

PD Dr. med. David Liebetanz

Oberarzt der Abteilung

Klinische Neurophysiologie
Prof. Dr. med. Martin Sommer

Oberarzt der Abteilung

Klinische Neurophysiologie

Dr. med. Jessica Grundey

Assistenzärztin der Abteilung

Klinische Neurophysiologie 


\subsection{Subject consent form}

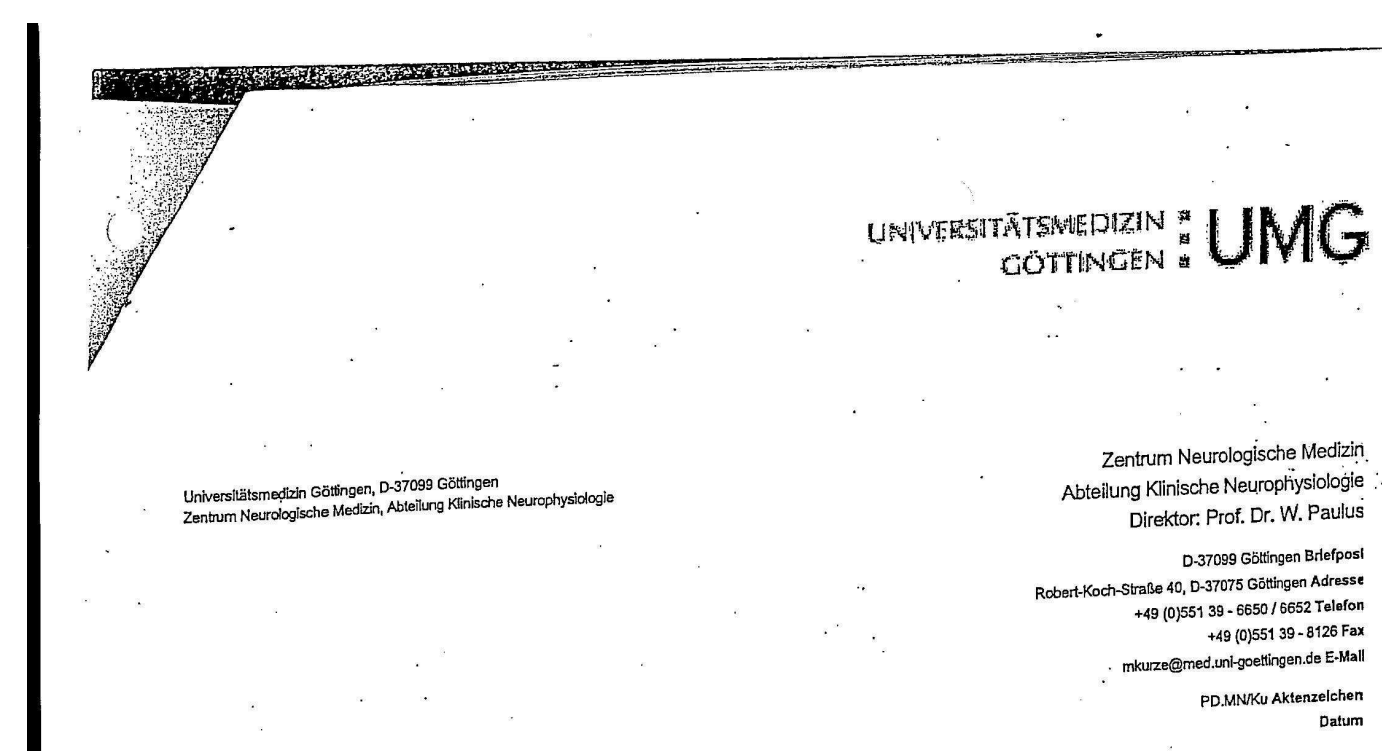

(1) Einverständniserklärung für Teilnehmer über die Studie: Dopaminerge Modulation von Neuroplastizität beim Menschen: Neurophysiologische Basis und behaviorale Auswirkungen Version 1-1, 19.05.2011

Herr/Frau Dr. hat mir heute anhand der Hinweise auf dem Informationsbogen für Teilnehmer an o.g. Studie die Durchführung der Untersuchung erläutert. Ich habe diesbezüglich keine weiteren Fragen mehr. Alle mich interessierenden Fragen wurden ausreichend beantwortet.

Q. Ich erkläre darüber hinaus, daß ich alle Angaben zur Krankengeschichte wahrheitsgemäß gemacht habe. Mir ist bekannt, daß ich jederzeit ohne Angabe von Gründen die weitere Untersuchung Einverständniserklärung widerrufen sowie die Löschung meiner Daten beantragen bzw. die Einwilligung zur Nutzung meiner Daten widerrufen kann, ohne daß mir daraus Nachteile entstehen.

Ich bin bereit, an der Studie teilzunehmen.

Meine personenbezogenen Daten werden in Papierform und elektronisch auf einem Laborcomputer der Abteilung Klinische Neurophysiologie erhoben, gespeichert und verarbeitet. Auf die Daten haben ausschließlich die Studienärzte Zugriff. Die Daten werden 15 Jahre nach Erhebung gespeichert, werden an keine weiteren Institutionen oder Personen mit Ausnahme der Studienärzte weitergegeben und werden auf Anfrage bei Widerruf der Studienteilnahme gelöscht. Die Datennutzung erfolgt 


\section{References}

Abe K, Niikura Y, Fujimoto T, Akaishi T, Misawa M (2008): Involvement of dopamine D2 receptors in the induction of long-term potentiation in the basolateral amygdaladentate gyrus pathway of anesthetized rats. Neuropharmacology 55, 1419-1424

Bailey CH, Giustetto M, Huang YY, Hawkins RD, Kandel ER (2000): Is heterosynaptic modulation essential for stabilizing Hebbian plasticity and memory? Nat Rev Neurosci $1,11-20$

Barchas JD, Akil H, Elliott GR, Holman RB, Watson SJ (1978): Behavioral neurochemistry: neuroregulators and behavioral states. Science 200, 964-973

Barker AT, Freeston I (2007): Transcranial magnetic stimulation. Scholarpedia 2, 2936

Barker AT, Jalinous R, Freeston IL (1985): Non-invasive magnetic stimulation of human motor cortex. Lancet 1, 1106-1107

Batsikadze G, Moliadze V, Paulus W, Kuo M-F, Nitsche MA (2013): Partially non-linear stimulation intensity-dependent effects of direct current stimulation on motor cortex excitability in humans. J Physiol 591, 1987-2000

Bear MF, Malenka RC (1994): Synaptic plasticity: LTP and LTD. Curr Opin Neurobiol 4 , 389-399

Benoit-Marand M, Borrelli E, Gonon F (2001): Inhibition of dopamine release via presynaptic D2 receptors: time course and functional characteristics in vivo. J Neurosci 21, 9134-9141

Bliss TV, Collingridge GL, Morris RG (2003): Introduction. Long-term potentiation and structure of the issue. Philos Trans R Soc B Biol Sci 358, 607-611

Boggio PS, Valasek CA, Campanhã C, Giglio ACA, Baptista NI, Lapenta OM, Fregni F (2011): Non-invasive brain stimulation to assess and modulate neuroplasticity in Alzheimer's disease. Neuropsychol Rehabil 21, 703-716

Breitenstein C, Korsukewitz C, Flöel A, Kretzschmar T, Diederich K, Knecht S (2006): Tonic dopaminergic stimulation impairs associative learning in healthy subjects. Neuropsychopharmacology $\underline{31}, 2552-2564$

Calabresi P, Maj R, Pisani A, Mercuri NB, Bernardi G (1992): Long-term synaptic depression in the striatum: physiological and pharmacological characterization. J Neurosci $12,4224-4233$

Calabresi P, Gubellini P, Centonze D, Picconi B, Bernardi G, Chergui K, Svenningsson P, Fienberg AA, Greengard P (2000): Dopamine and cAMP-regulated phosphoprotein 32 $\mathrm{kDa}$ controls both striatal long-term depression and long-term potentiation, opposing forms of synaptic plasticity. J Neuroscience 20, 8443-8451 
Carrera MP, Carey RJ, Dias FRC, de Matos LW (2011): Reversal of apomorphine locomotor sensitization by a single post-conditioning trial treatment with a low autoreceptor dose of apomorphine: A memory re-consolidation approach. Pharmacol Biochem Behav 99, 29-34

Centonze D, Picconi B, Gubellini P, Bernardi G, Calabresi P (2001): Dopaminergic control of synaptic plasticity in the dorsal striatum. Eur J Neurosci 13, 1071-1077

Centonze D, Grande C, Usiello A, Gubellini P, Erbs E, Martin AB, Pisani A, Tognazzi N, Bernardi G, Moratalla R, et al. (2003): Receptor subtypes involved in the presynaptic and postsynaptic actions of dopamine on striatal interneurons. J Neurosci 23, 62456254

Chen Z, Ito K, Fujii S, Miura M, Furuse H, Sasaki H, Kaneko K, Kato H, Miyakawa H (1996): Roles of dopamine receptors in long-term depression: enhancement via D1 receptors and inhibition via D2 receptors. Receptors Channels 4 , 1-8

Citri A, Malenka RC (2008): Synaptic Plasticity: Multiple Forms, Functions, and Mechanisms. Neuropsychopharmacology 33, 18-41

Classen J, Liepert J, Wise SP, Hallett M, Cohen LG (1998): Rapid Plasticity of Human Cortical Movement Representation Induced by Practice. J Neurophysiol 79, 1117-1123

Classen J, Wolters A, Stefan K, Wycislo M, Sandbrink F, Schmidt A, Kunesch E (2004): Paired associative stimulation. Suppl Clin Neurophysiol 57, 563-569

Cools R, D’Esposito M (2011): Inverted-U-Shaped Dopamine Actions on Human Working Memory and Cognitive Control. Biol Psychiatry 69, e113-e125

Costa A, Peppe A, Mazzù I, Longarzo M, Caltagirone C, Carlesimo GA (2014): Dopamine treatment and cognitive functioning in individuals with Parkinson's disease: the „Cognitive flexibility“ hypothesis seems to work. Behav Neurol 2014, 260896

D' Alcantara P, Schiffmann SN, Swillens S (2003): Bidirectional synaptic plasticity as a consequence of interdependent $\mathrm{Ca} 2+$-controlled phosphorylation and dephosphorylation pathways. Eur J Neurosci 17, 2521-2528

Datta A, Truong D, Minhas P, Parra LC, Bikson M (2012): Inter-Individual Variation during Transcranial Direct Current Stimulation and Normalization of Dose Using MRIDerived Computational Models. Front Psychiatry 3, 91

Di Chiara G, Porceddu ML, Vargiu L, Argiolas A, Gessa GL (1976): Evidence for dopamine receptors mediating sedation in the mouse brain. Nature 264, 564-567

Di Lazzaro V, Oliviero A, Profice P, Saturno E, Pilato F, Insola A, Mazzone P, Tonali P, Rothwell JC (1998): Comparison of descending volleys evoked by transcranial magnetic and electric stimulation in conscious humans. Electroencephalogr Clin Neurophysiol 109, 397-401 
Dimyan MA, Cohen LG (2011): Neuroplasticity in the context of motor rehabilitation after stroke. Nat Rev Neurol 7, 76-85

Durstewitz D, Seamans JK, Sejnowski TJ (2000): Dopamine-mediated stabilization of delay-period activity in a network model of prefrontal cortex. J Neurophysiol $\underline{83}, 1733-$ 1750

Floel A, Cohen LG (2010): Recovery of function in humans: Cortical stimulation and pharmacological treatments after stroke. Neurobiol Dis 37, 243-251

Floel A, Hummel F, Breitenstein C, Knecht S, Cohen LG (2005): Dopaminergic effects on encoding of a motor memory in chronic stroke. Neurology $65,472-474$

Flöel A, Breitenstein C, Hummel F, Celnik P, Gingert C, Sawaki L, Knecht S, Cohen LG (2005): Dopaminergic influences on formation of a motor memory. Ann Neurol 58, 121130

Fresnoza S, Stiksrud E, Klinker F, Liebetanz D, Paulus W, Kuo M-F, Nitsche MA (2014a): Dosage-dependent effect of dopamine D2 receptor activation on motor cortex plasticity in humans. J Neuroscience 34, 10701-10709

Fresnoza S, Paulus W, Nitsche MA, Kuo M-F (2014b): Nonlinear dose-dependent impact of D1 receptor activation on motor cortex plasticity in humans. J Neurosci $\underline{34}, 2744-$ 2753

Frey U, Hartmann S, Matthies H (1989): Domperidone, an inhibitor of the D2-receptor, blocks a late phase of an electrically induced long-term potentiation in the CA1-region in rats. Biomed Biochim Acta 48, 473-476

Friston KJ, Grasby PM, Bench CJ, Frith CD, Cowen PJ, Liddle PF, Frackowiak RSJ, Dolan R (1992): Measuring the neuromodulatory effects of drugs in man with positron emission tomography. Neurosci Lett 141, 106-110

Fritsch B, Reis J, Martinowich K, Schambra HM, Ji Y, Cohen LG, Lu B (2010): Direct Current Stimulation Promotes BDNF-Dependent Synaptic Plasticity: Potential Implications for Motor Learning. Neuron 66, 198-204

Grundey J, Freznosa S, Klinker F, Lang N, Paulus W, Nitsche MA (2013): Cortical excitability in smoking and not smoking individuals with and without nicotine. Psychopharmacology (Berl) 229, 653-664

Gu Q (2002): Neuromodulatory transmitter systems in the cortex and their role in cortical plasticity. Neuroscience $111,815-835$

Gurden H, Takita M, Jay TM (2000): Essential role of D1 but not D2 receptors in the NMDA receptor-dependent long-term potentiation at hippocampal-prefrontal cortex synapses in vivo. J Neurosci 20, RC106

Hallett M (2001): Plasticity of the human motor cortex and recovery from stroke. Brain 
Res Rev $\underline{36}, 169-174$

Hansen N, Manahan-Vaughan D (2014): Dopamine D1/D5 receptors mediate informational saliency that promotes persistent hippocampal long-term plasticity. Cereb Cortex 1991 24, 845-858

Hebb DO: Organization of behavior. Wiley, New York 1949

Hsieh GC, Hollingsworth PR, Martino B, Chang R, Terranova MA, O’Neill AB, Lynch JJ, Moreland RB, Donnelly-Roberts DL, Kolasa T, et al. (2004): Central Mechanisms Regulating Penile Erection in Conscious Rats: The Dopaminergic Systems Related to the Proerectile Effect of Apomorphine. J Pharmacol Exp Ther 308, 330-338

Huang Y-Y, Simpson E, Kellendonk C, Kandel ER (2004): Genetic evidence for the bidirectional modulation of synaptic plasticity in the prefrontal cortex by D1 receptors. Proc Natl Acad Sci U S A 101, 3236-3241

Jay TM (2003): Dopamine: a potential substrate for synaptic plasticity and memory mechanisms. Prog Neurobiol 69, 375-390

Kerr JN, Wickens JR (2001): Dopamine D-1/D-5 receptor activation is required for longterm potentiation in the rat neostriatum in vitro. J Neurophysiol $85,117-124$

Knable MB, Barci BM, Bartko JJ, Webster MJ, Torrey EF (2002): Molecular abnormalities in the major psychiatric illnesses: Classification and Regression Tree (CRT) analysis of post-mortem prefrontal markers. Mol Psychiatry 7, 392-404 7

Knecht S, Breitenstein C, Bushuven S, Wailke S, Kamping S, Flöel A, Zwitserlood P, Ringelstein EB (2004): Levodopa: faster and better word learning in normal humans. Ann Neurol 56, 20-26

Kolb B, Gibb R (2014): Searching for the principles of brain plasticity and behavior. Cortex 58, 251-260

Koller W, Stacy M (2004): Other formulations and future considerations for apomorphine for subcutaneous injection therapy. Neurology $62,22-26$

Ksiazek-Winiarek DJ, Szpakowski P, Glabinski A (2015): Neural Plasticity in Multiple Sclerosis: The Functional and Molecular Background. Neural Plast 2015, 1-11

Kuo MF, Paulus W, Nitsche MA (2008): Boosting focally-induced brain plasticity by dopamine. Cereb Cortex 1991 18, 648-651

Lemon N, Manahan-Vaughan D (2006): Dopamine D1/D5 receptors gate the acquisition of novel information through hippocampal long-term potentiation and long-term depression. J Neurosci 26, 7723-7729

LeWitt PA (2004): Subcutaneously administered apomorphine: pharmacokinetics and metabolism. Neurology 62 , S8-11 
Liebetanz D (2002): Pharmacological approach to the mechanisms of transcranial DC stimulation-induced after-effects of human motor cortex excitability. Brain 125, 2238 2247

Liew SL, Santarnecchi E, Buch ER, Cohen LG (2014): Non-invasive brain stimulation in neurorehabilitation: local and distant effects for motor recovery. Front Hum Neurosci $\underline{8}$, $1-15$

Lisman JE (2001): Three Ca ${ }^{2+}$ levels affect plasticity differently: the LTP zone, the LTD zone and no man's land. J Physiol 532, 285-285

Malenka RC, Bear MF (2004): LTP and LTD. Neuron 44, 5-21

Malinow R, Malenka RC (2002): AMPA RECEPTOR TRAFFICKING AND SYNAPTIC PLASTICITY. Annu Rev Neurosci 25, 103-126

Manahan-Vaughan D, Kulla A (2003): Regulation of depotentiation and long-term potentiation in the dentate gyrus of freely moving rats by dopamine D2-like receptors. Cereb Cortex 1991 13, 123-135

Misonou H, Mohapatra DP, Park EW, Leung V, Zhen D, Misonou K, Anderson AE, Trimmer JS (2004): Regulation of ion channel localization and phosphorylation by neuronal activity. Nat Neurosci $7,711-718$

Moal ML, Simon H (1991): Mesocorticolimbic dopaminergic network: functional and regulatory roles. Physiol Rev $\underline{71}, 155-234$

Mockett BG, Guévremont D, Williams JM, Abraham WC (2007): Dopamine D1/D5 receptor activation reverses NMDA receptor-dependent long-term depression in rat hippocampus. J Neurosci 27, 2918-2926

Momiyama T, Sim JA, Brown DA (1996): Dopamine D1-like receptor-mediated presynaptic inhibition of excitatory transmission onto rat magnocellular basal forebrain neurones. J Physiol 495 ( Pt 1), 97-106

Monte-Silva K, Kuo M-F, Thirugnanasambandam N, Liebetanz D, Paulus W, Nitsche MA (2009): Dose-dependent inverted U-shaped effect of dopamine (D2-like) receptor activation on focal and nonfocal plasticity in humans. J Neurosci $29,6124-6131$

Monte-Silva K, Liebetanz D, Grundey J, Paulus W, Nitsche MA (2010): Dosage-dependent non-linear effect of L-dopa on human motor cortex plasticity. J Physiol 588, 3415-3424

Monte-Silva K, Ruge D, Teo JT, Paulus W, Rothwell JC, Nitsche MA (2011): D2 receptor block abolishes $\theta$ burst stimulation-induced neuroplasticity in the human motor cortex. Neuropsychopharmacology $36,2097-2102$

Montoya A, Lal S, Menear M, Duplessis E, Thavundayil J, Schmitz N, Lepage M (2008): Apomorphine effects on episodic memory in young healthy volunteers. 
Neuropsychologia $46,292-300$

Moreau C, Meguig S, Corvol J-C, Labreuche J, Vasseur F, Duhamel A, Delval A, Bardyn T, Devedjian J-C, Rouaix N, et al. (2015): Polymorphism of the dopamine transporter type 1 gene modifies the treatment response in Parkinson's disease. Brain J Neurol 138, 1271-1283

Nahas Z (2003): Handbook of Transcranial Magnetic Stimulation. J Psychiatry Neurosci 28, 373-375

Nitsche MA, Paulus W (2000): Excitability changes induced in the human motor cortex by weak transcranial direct current stimulation. J Physiol $527 \mathrm{Pt} \mathrm{3,} \mathrm{633-639}$

Nitsche MA, Paulus W (2001): Sustained excitability elevations induced by transcranial DC motor cortex stimulation in humans. Neurology 57, 1899-1901

Nitsche MA, Nitsche MS, Klein CC, Tergau F, Rothwell JC, Paulus W (2003a): Level of action of cathodal DC polarisation induced inhibition of the human motor cortex. Clin Neurophysiol 114, 600-604

Nitsche MA, Fricke K, Henschke U, Schlitterlau A, Liebetanz D, Lang N, Henning S, Tergau F, Paulus W (2003b): Pharmacological Modulation of Cortical Excitability Shifts Induced by Transcranial Direct Current Stimulation in Humans. J Physiol 553, 293-301

Nitsche MA, Liebetanz D, Schlitterlau A, Henschke U, Fricke K, Frommann K, Lang N, Henning S, Paulus W, Tergau F (2004): GABAergic modulation of DC stimulationinduced motor cortex excitability shifts in humans. Eur J Neurosci 19, 2720-2726

Nitsche MA, Lampe C, Antal A, Liebetanz D, Lang N, Tergau F, Paulus W (2006): Dopaminergic modulation of long-lasting direct current-induced cortical excitability changes in the human motor cortex. Eur J Neurosci 23, 1651-1657

Nitsche MA, Doemkes S, Karaköse T, Antal A, Liebetanz D, Lang N, Tergau F, Paulus W (2007): Shaping the effects of transcranial direct current stimulation of the human motor cortex. J Neurophysiol 97, 3109-3117

Nitsche MA, Cohen LG, Wassermann EM, Priori A, Lang N, Antal A, Paulus W, Hummel F, Boggio PS, Fregni F, Pascual-Leone A (2008): Transcranial direct current stimulation: State of the art 2008. Brain Stimul 1, 206-223

Nitsche MA, Kuo M-F, Grosch J, Bergner C, Monte-Silva K, Paulus W (2009): D1-receptor impact on neuroplasticity in humans. J Neurosci 29, 2648-2653

Nitsche MA, Müller-Dahlhaus F, Paulus W, Ziemann U (2012): The pharmacology of neuroplasticity induced by non-invasive brain stimulation: building models for the clinical use of CNS active drugs: Pharmacology of non-invasive brain stimulation. J Physiol 590, 4641-4662

Otani S, Blond O, Desce JM, Crépel F (1998): Dopamine facilitates long-term depression of glutamatergic transmission in rat prefrontal cortex. Neuroscience $85,669-676$ 
Otmakhova NA, Lisman JE (1996): D1/D5 dopamine receptor activation increases the magnitude of early long-term potentiation at CA1 hippocampal synapses. J Neurosci $\underline{16}$, 7478-7486

Pascual-Leone A, Amedi A, Fregni F, Merabet LB (2005): The plastic human brain cortex. Annu Rev Neurosci 28, 377-401

Passamonti L, Salsone M, Toschi N, Cerasa A, Giannelli M, Chiriaco C, Cascini GL, Fera F, Quattrone A (2013): Dopamine-transporter levels drive striatal responses to apomorphine in Parkinson's disease. Brain Behav 3, 249-262

Pierantozzi M, Palmieri M, Marciani M, Bernardi G, Giacomini P, Stanzione P (2001): Effect of apomorphine on cortical inhibition in Parkinson's disease patients: a transcranial magnetic stimulation study. Exp Brain Res 141, 52-62

Rioult-Pedotti M-S, Friedman D, Donoghue JP (2000): Learning-Induced LTP in Neocortex. Science 290, 533-536

Rösser N, Heuschmann P, Wersching H, Breitenstein C, Knecht S, Flöel A (2008): Levodopa improves procedural motor learning in chronic stroke patients. Arch Phys Med Rehabil 89, 1633-1641

Rothwell JC (1993): Evoked potentials, magnetic stimulation studies, and event-related potentials. Curr Opin Neurol $\underline{6}$, 715-723

Sajikumar S, Frey JU (2004): Late-associativity, synaptic tagging, and the role of dopamine during LTP and LTD. Neurobiol Learn Mem 82, 12-25

Sanes JN, Donoghue JP (2000): Plasticity and Primary Motor Cortex. Annu Rev Neurosci $23,393-415$

Scheidtmann K, Fries W, Müller F, Koenig E (2001): Effect of levodopa in combination with physiotherapy on functional motor recovery after stroke: a prospective, randomised, double-blind study. Lancet Lond Engl 358, 787-790

Schellekens AF, van Oosterwijck AW, Ellenbroek B, de Jong CA, Buitelaar JK, Cools L, Verkes RJ (2009): The dopamine agonist apomorphine differentially affects cognitive performance in alcohol dependent patients and healthy controls. Eur Neuropsychopharmacol 19, 68-73

Schellekens AFA, Grootens KP, Neef C, Movig KLL, Buitelaar JK, Ellenbroek B, Verkes RJ (2010): Effect of apomorphine on cognitive performance and sensorimotor gating in humans. Psychopharmacology (Berl) 207, 559-569

Schmitz Y, Benoit-Marand M, Gonon F, Sulzer D (2003): Presynaptic regulation of dopaminergic neurotransmission. J Neurochem 87, 273-289

Schwab RS, Amador LV, Lettvin JY (1951): Apomorphine in Parkinson's disease. Trans 
Am Neurol Assoc 56, 251-253

Seamans JK, Yang CR (2004): The principal features and mechanisms of dopamine modulation in the prefrontal cortex. Prog Neurobiol 74, 1-58

Sjöström J, Gerstner W (2010): Spike-timing dependent plasticity. Scholarpedia $\underline{5}, 1362$

Spencer JP, Murphy KP (2000): Bi-directional changes in synaptic plasticity induced at corticostriatal synapses in vitro. Exp Brain Res 135, 497-503

Stacy M (2004): Apomorphine: North American clinical experience. Neurology $\underline{62}$

Stagg CJ, Bachtiar V, Johansen-Berg H (2011): The Role of GABA in Human Motor Learning. Curr Biol 21, 480-484

Stefan K, Kunesch E, Cohen LG, Benecke R, Classen J (2000): Induction of plasticity in the human motor cortex by paired associative stimulation. Brain $123,572-584$

Stefan K, Kunesch E, Benecke R, Cohen LG, Classen J (2002): Mechanisms of enhancement of human motor cortex excitability induced by interventional paired associative stimulation. J Physiol 543, 699-708

Strube W, Bunse T, Nitsche MA, Nikolaeva A, Palm U, Padberg F, Falkai P, Hasan A (2016): Bidirectional variability in motor cortex excitability modulation following $1 \mathrm{~mA}$ transcranial direct current stimulation in healthy participants. Physiol Rep $\underline{4}$, e12884

Tang K, Low MJ, Grandy DK, Lovinger DM (2001): Dopamine-dependent synaptic plasticity in striatum during in vivo development. Proc Natl Acad Sci U S A 98, 12551260

Thirugnanasambandam N, Grundey J, Paulus W, Nitsche MA (2011): Dose-dependent nonlinear effect of L-DOPA on paired associative stimulation-induced neuroplasticity in humans. J Neurosci 31, 5294-5299

Trepel C, Racine RJ (2000): GABAergic modulation of neocortical long-term potentiation in the freely moving rat. Synapse $35,120-128$

Tseng KY, O'Donnell P (2004): Dopamine-glutamate interactions controlling prefrontal cortical pyramidal cell excitability involve multiple signaling mechanisms. J Neurosci Off J Soc Neurosci 24, 5131-5139

Uno K, Nishizawa D, Seo S, Takayama K, Matsumura S, Sakai N, Ohi K, Nabeshima T, Hashimoto R, Ozaki N, et al. (2015): The Piccolo Intronic Single Nucleotide Polymorphism rs13438494 Regulates Dopamine and Serotonin Uptake and Shows Associations with Dependence-Like Behavior in Genomic Association Study. Curr Mol Med 15, 265-274

Usiello A, Baik JH, Rougé-Pont F, Picetti R, Dierich A, LeMeur M, Piazza PV, Borrelli E (2000): Distinct functions of the two isoforms of dopamine D2 receptors. Nature 408 , 
199-203

Vallence A-M, Ridding MC (2014): Non-invasive induction of plasticity in the human cortex: Uses and limitations. Cortex $58,261-271$

Vallone D, Picetti R, Borrelli E (2000): Structure and function of dopamine receptors. Neurosci Biobehav Rev 24, 125-132

Wiethoff S, Hamada M, Rothwell JC (2014): Variability in response to transcranial direct current stimulation of the motor cortex. Brain Stimul 7, 468-475

Wolf ME, Roth RH (1990): Autoreceptor regulation of dopamine synthesis. Ann N Y Acad Sci 604, 323-343

Yamada K, Furukawa T (1980): Direct evidence for involvement of dopaminergic inhibition and cholinergic activation in yawning. Psychopharmacology (Berl) 67, 39-43

Zheng P, Zhang XX, Bunney BS, Shi WX (1999): Opposite modulation of cortical Nmethyl-D-aspartate receptor-mediated responses by low and high concentrations of dopamine. Neuroscience 91, 527-535

Ziemann U, Reis J, Schwenkreis P, Rosanova M, Strafella A, Badawy R, Müller-Dahlhaus F (2015): TMS and drugs revisited 2014. Clin Neurophysiol 126, 1847-1868 


\section{Acknowlegements}

I would like to thank Prof. Dr. med Michael Nitsche for giving me the possibility to work in his research group and his guidance.

Moreover I would like to thank Giorgi Batsikadze for his consuming supervision of my work and his great support.

My thanks is also directed to my other supervisors Shane Fresnoza and Min-Fang Kuo. 


\section{Curriculum Vitae}

My name is Lynn Elena Müller. I was born on September 28 ${ }^{\text {th }}, 1986$ in Essen, Germany.

I finished my school education at Ursulaschule Osnabrück with Abitur (equivalent to A level). In September 2006 I started to study Neuropsychology at the University College Maastricht, which I completed with Cum Laude in July 2009. In April 2010 I started to study human medicine at Georg-August-Universität in Göttingen. In April 2013 I changed to Charité Universitätsmedizin Berlin, where I obtained my license to practice medicine in December 2016.

I have done various internships, among others at the Psychiatry department of the Royal College of Surgeons, where I was a co-author of a paper. Furthermore I was a student research assistant at the University Maastricht. Since May 2013 I was a MDstudent at the department of Clinical Neurophysiology of the University of Göttingen (group leader Prof. Nitsche).

I am active in tennis- and volleyball clubs. Furthermore I was active as a local exchange officer in Berlin for IFMSA. Among various other part-time jobs I have been active in tutoring Biology. Since March 2017 I am working as a resident in the department of internal medicine at the Oberhavel Klinikum Hennigsdorf. 